Portland State University

PDXScholar

\title{
A preliminary investigation of the lithological characteristics of the Troutdale Formation in portions of the Camas, Sandy, Washougal, and Bridal Veil quadrangles
}

David Lee Cole

Portland State University

Follow this and additional works at: https://pdxscholar.library.pdx.edu/open_access_etds

Part of the Geology Commons, and the Stratigraphy Commons Let us know how access to this document benefits you.

\section{Recommended Citation}

Cole, David Lee, "A preliminary investigation of the lithological characteristics of the Troutdale Formation in portions of the Camas, Sandy, Washougal, and Bridal Veil quadrangles" (1982). Dissertations and Theses. Paper 3248.

https://doi.org/10.15760/etd.3239

This Thesis is brought to you for free and open access. It has been accepted for inclusion in Dissertations and Theses by an authorized administrator of PDXScholar. Please contact us if we can make this document more accessible: pdxscholar@pdx.edu. 
AN ABSTRACT OF THE THESIS of David Lee Cole for the Master of Science in Geology is presented November 3, 1982.

Title: A Preliminary Investigation of the Lithological Characteristics of the Troutdale Formation in Portions of the Camas, Sandy, Washougal, and Bridal Veil Quadrangles.

APPROVED BY MEMBERS OF THE THESIS COMMITTEE:

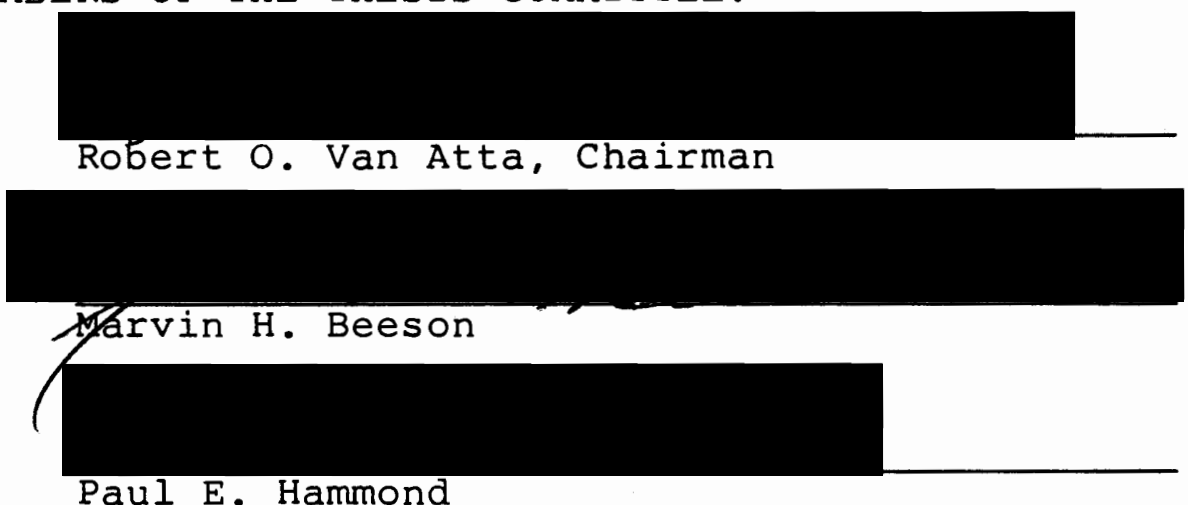

The study area encompasses a region of about 80 square kilometers, centered about Corbett, Oregon. Sieve analyses suggest that the Troutdale Formation is composed of a conglomerate, a coarse-grained sandstone, and a siltstone lithofacies. Measured sections data show that 56 to 60 percent of the Troutdale Formation's exposures are composed of the conglomerate lithofacies. The coarsegrained sandstone lithofacies makes up 34 to 38 percent, while the siltstone lithofacies makes up only 4 to 8 percent. Pebble count data show that the representation 
of basalt varies from 69 to 100 percent, with an average of 85 percent, while quartzite varies from 0 to 25 percent, with an average of 9 percent. Geochemical data show that at least one formal member and two informal members of the Columbia River Basalt Group (Frenchman Springs, Grande Ronde High Mg, and Grande Ronde Low Mg) compose part of the detritus. The geochemical data also show that rocks of the Boring Lavas or similar lavas are intercalated with the Troutdale Formation, high in the section. Grain mount petrographic data show that volcanic rock fragments are the dominant component in the coarse sand fraction of the Troutdale Formation. Many of the volcanic rock fragments contain brown glass with an index of refraction of $1.583 \pm 0.001$, which indicates a mafic composition (silica content of $50 \pm 1$ percent). The representation of volcanic rock fragments varies from 29 to 98 percent, with an average of 75 percent. Sedimentary rock fragments, such as chert, vary from 0 to 17 percent, with an average of 5 percent. Biotite ranges from 0 to 12 percent, with an average of 2 percent. Two-thirds of the samples which contain sedimentary rock fragments also contain biotite. Orthopyroxene varies from 0 to 18 percent, with an average of 5 percent. The samples with the three greatest amounts of orthopyroxene do not contain sedimentary rock fragments or biotite.

The average bearing of paleocurrent measurements is $285^{\circ}$. A rose diagram representation of the paleocurrent 
data shows that the largest class interval (25 percent of all measurements) is centered about a bearing of $285^{\circ}$. Other class intervals indicate the presence of anabranches and/or distributaries, flowing toward the northwest and southwest.

A bed relief index value of 12.1 , along with the granulometric and measured sections data, strongly suggest that the Troutdale Formation was deposited in the braidedstream depositional environment. The pebble count, geochemical, and grain mount data show that most of the clastic material of the Troutdale Formation was proximally derived. Distal sources also contributed significant amounts of the detritus. 
A PRELIMINARY INVESTIGATION OF THE LITHOLOGICAL CHARACTERISTICS OF THE TROUTDALE FORMATION IN PORTIONS OF THE CAMAS, SANDY, WASHOUGAL, AND BRIDAL VEIL QUADRANGLES

by

DAVID LEE COLE

A thesis submitted in partial fulfillment of the requirements for the degree of

MASTER OF SCIENCE

in

GEOLOGY

Portland State University

1983 
TO THE OFFICE OF GRADUATE STUDIES AND RESEARCH:

The members of the Committee approve the thesis

of David Lee Cole presented November 3, 1982.
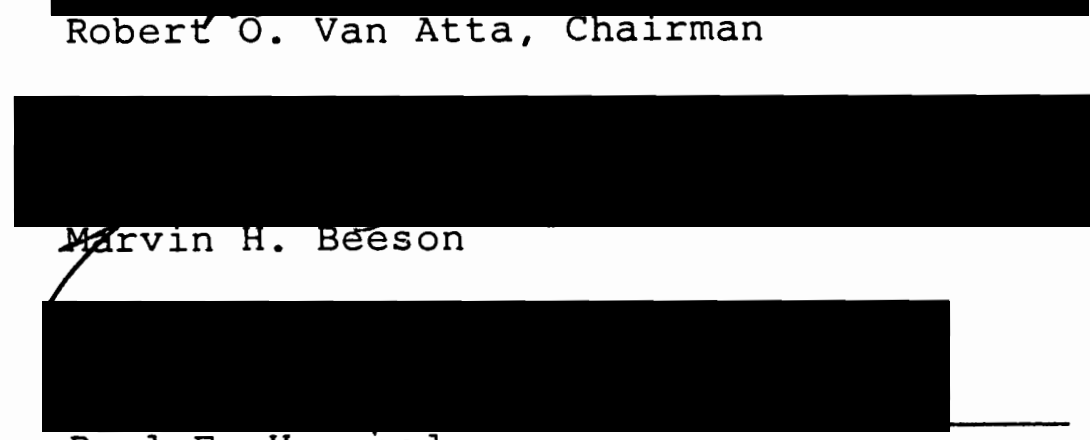

Paul E. Hammond

APPROVED :

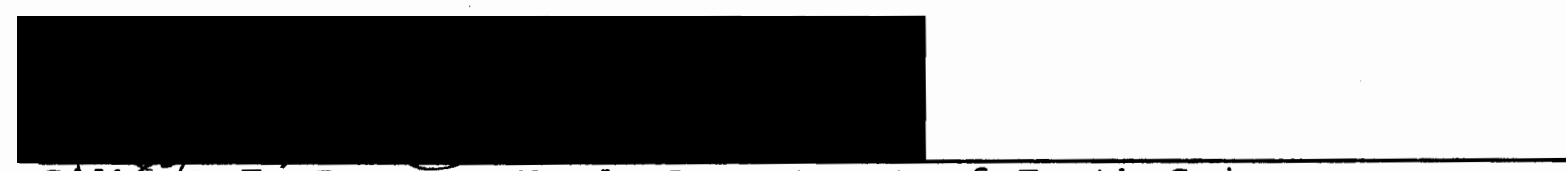

Givbert T. Benson, Head, Department of Earth Sciences

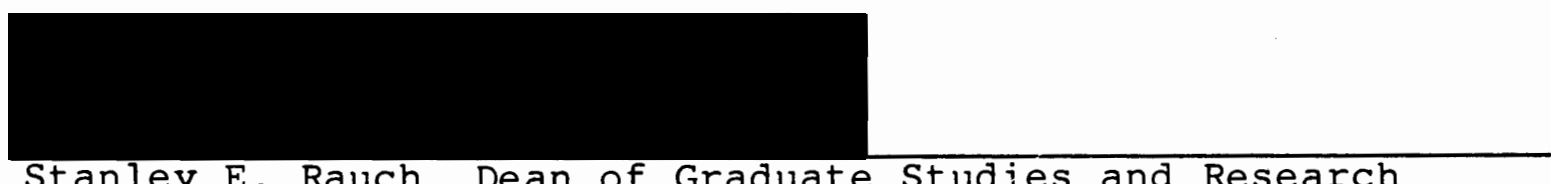




\section{ACKNOWLEDGMENTS}

The author is indebted to the faculty and staff of the Earth Sciences Department for their help with outcrop selection, observations of outcrop sedimentology, identification of basalt clast origins, manuscript editing, data analysis, and other helpful and constructive comments. The author wishes to thank Thomas Koler and Steven Kee for their help in sample collection and useful thoughts concerning outcrop sedimentology. Deep appreciation is expressed for access to Paul Howell's unpublished fieldwork which helped the author locate several important stratigraphic sections, and aided in determining the geologic history of the study area. Howell's work led to the foundation of the Howell Fund from which an award was made for completion of this study. Appreciation is expressed also for this award. Finally, I wish to thank my parents, without whom none of this would be possible. 
TABLE OF CONTENTS

PAGE

ACKNOWLEDGMENTS . . . . . . . . . . . . . . iii

LIST OF TABLES. . . . . . . . . . . . . . . . vi vi

LIST OF FIGURES . . . . . . . . . . . . . . vii

INTRODUCTION. . . . . . . . . . . . . . . . 1

PURPOSE OF STUDY. . . . . . . . . . . . . 1

METHODS OF STUDY. . . . . . . . . . . 2

LOCATION AND EXTENT OF STUDY AREA . . . . . . 2

PREVIOUS WORK .............. . 3

LOCAL GEOLOGIC SETTING. . . . . . . . . 11

DATA PRESENTATION AND DISCUSSION. . . . . . . . 15

TROUTDALE LITHOFACIES . . . . . . . . 15

Conglomerate Lithofacies. . . . . . . 21

Coarse-grained Sandstone Lithofacies. . . 22

Siltstone Lithofacies........ . 22

MEASURED SECTIONS ............ . . . 23

PETROGRAPHY ................. 32

Pebble Counts............ . 34

Instrumental Neutron Activation Analysis. . 40

Grain Mount Petrography . . . . . . . 42

Compositional Trends. . . . . . . . 50

PALEOCURRENT DIRECTIONS . . . . . . . . 52 
PAGE

DEPOSITIONAL ENVIRONMENT. • • • • • • • • • • • • •

REFERENCES CITED.

APPENDIX 


\section{LIST OF TABLES}

TABLE

PAGE

I Summary of Lithofacies Parameters. . . . . . 16

I Measured Sections Data . . . . . . . . . 25

II Base Elevations, Top Elevations, and

Thicknesses of the Measured Sections. . . 26

IV Pebble Count Data. . . . . . . . . . . 37

V Geochemical Parent Rock-type Determinations

for Basalt Clast Samples . . . . . . . . 42

VI Grain Mount Sample Numbers, Lithofacies, and Localities . . . . . . . . . . . . 46

VII Percentages of Components in Grain Mount Samples . . . . . . . . . . . . . . 47

VIII Summary of Paleocurrent Data . • • • • • . 53 


\section{LIST OF FIGURES}

FIGURE

PAGE

1. Location of Study Area . . . . . . . . . 4

2. Sieve Analyses Sample Localities . . . . . . 17

3. Histogram of Conglomerate. Lithofacies Sieve Analysis . . • . . . . . . . . . . . . 18

4. Histogram of Coarse-grained Sandstone Lithofacies Sieve Analysis . . . . . . . . 19

5. Cumulative Size Frequency Curves of the Conglomerate and Coarse-grained Sandstone Lithofacies. • . . . . . . . . . . . 20

6. Locality Map of Measured Sections. . . . . . 24

7. Explanation of Units Shown in Figure 8 . • . . 26

8. Correlation Chart of Measured Sections . . . 27

9. Representative Composite Troutdale Section . . 30

10. Bed Relief Index Calculation for Outcrop of Conglomerate Lithofacies . . . . . . . . 33

11. Locality Map of Pebble Count Samples . • • . 35

12. Locality Map of Grain Mount Samples. . . . . 43

13. Map Showing Locations and Directions of Averaged Paleocurrent Measurements . . . . . 54

14. Rose Diagram Representation of Paleocurrent Data • • • • • • • • . . • • • • . • 


\section{INTRODUCTION}

Cataclysmic geologic events, such as vast outpouring of lava, stretching for hundreds of kilometers, and gigantic floods which backed up water into the willamette Valley, after rushing westward from as far away as Montana, are part of the geologic history of the Pacific Northwest. Studying the geologic record of the Pacific Northwest is essential to understanding its geologic history. Part of the geologic record of the Pacific Northwest is known as the Troutdale Formation.

\section{PURPOSE OF STUDY}

In order to gain a better understanding of the geologic history surrounding the deposition of the Troutdale Formation, its lithological characteristics were investigated, using various sampling and analyzing methods. Analysis of the data derived from these methods helps to answer fundamental questions concerning the sedimentary rocks of the Troutdale Formation. The fundamental questions which are addressed include the following: the provenance of the Troutdale rocks, the development of a representative composite section of the Troutdale Formation, the environment within which the sedimentary rocks of the Troutdale Formation were deposited, and the presence of 
granulometric and compositional trends within the Troutdale Formation. Answers to these fundamental questions are important, because they help to unravel the intricate and fascinating geologic history of the Pacific Northwest.

\section{METHODS OF STUDY}

In order to understand the evolution of knowledge concerning the geologic history of the Troutdale Formation, a summary of previous work is presented. Following the summary of previous work, is a section on the local geologic setting. After this, the methods used in the present report, and the data derived from these methods, are presented and discussed. Next, a section on depositional environment is presented. Finally, a summary of the report is given.

In order of their presentation, the sampling and analyzing methods used in this report are: sieve analyses, measurement and description of vertical sections, a bed relief index calculation, pebble counts, instrumental neutron activation analysis of basalt clasts, grain mount petrography, and attitude measurements of primary sedimentary structures for paleocurrent analyses.

\section{LOCATION AND EXTENT OF STUDY AREA}

The study area (Figure 1 ) encompasses a region of about 80 square kilometers ( 30 square miles), and is located in portions of the following quadrangles: 
Camas ( 7.5 min.), Sandy ( 7.5 min.), Washougal ( 7.5 min.), and Bridal Veil ( 15 min.).

\section{PREVIOUS WORK}

In 1916, Williams published a report on the geology of the Columbia River Gorge, as interpreted from the Columbia River Highway. He referred to the Troutdale gravels as part of the Satsop Formation, which Bretz (1917) dealt with, shortly thereafter. Williams states that lavas are interbedded with the Troutdale Formation at crown Point.

In 1917, Bretz correlated the deposits of the presentday Troutdale Formation with the Satsop Formation of Oregon and Washington. In his section dealing with the Satsop Formation in the Columbia Valley west of the Cascade Range, Bretz said that quartzite is a common constituent of these deposits up to a distance of 16 kilometers south of the Columbia River, but has not been found more than 24 kilometers from the master stream. He found no upward slope of the Satsop surface toward the Coast Range on the western side of the Willamette Valley. On this side, Bretz said that the Formation terminates against hills of older basalt.

Allen (1932) described the Troutdale Formation's composition, based on 23 measured sections, and seven arbitrary physical divisions, which are: (1) boulder beds with sizes above $15 \mathrm{~cm}$, (2) boulder beds with sizes 

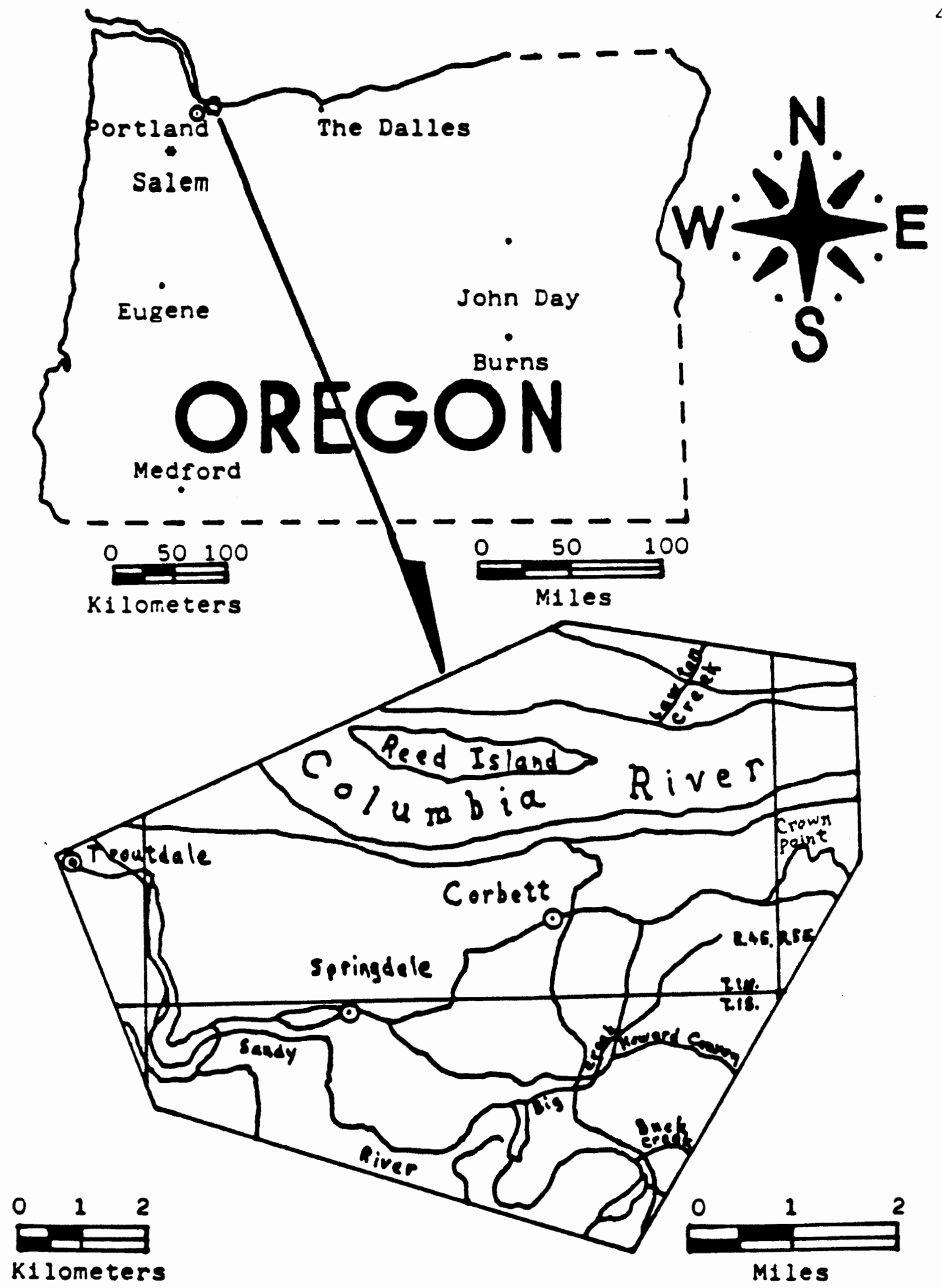

Figure 1. Location of study area. 
between 8 and $15 \mathrm{~cm}$, (3) pebble beds with sizes below $8 \mathrm{~cm},(4)$ beds of pebbly coarse-grained sandstone, (5) beds of coarse-grained sandstone, (6) beds of tuffaceous sandstone, and (7) beds of clay or fine tuff. He found that coarse-grained sandstone composes at least a third of the Troutdale Formation, with the small pebble beds coming next with about one fourth. Allen also found from channel sampling the gravel at 50 localities that the average composition of that portion of the conglomerate beds whose clasts are smaller than $8 \mathrm{~cm}$ in length is 40 percent basalt, 30 percent quartzite, and 30 percent andesite, in a matrix of coarse-grained sandstone.

In 1938, Hodge named and described the Troutdale Formation, some five years after he informally introduced the term. His study dealt with only that part of the Troutdale Formation occurring adjacent to the Columbia River Gorge. Hodge found that the overall occurrence of the Troutdale Formation is lens-shaped, with the thickest portion occurring in the willamette valley in the vicinity of Portland, Oregon. To the west, the Troutdale Formation thins out against the Portland Hills. Hodge states that much of the crudely-developed bedding in the coarse, poorly sorted sedimentary rocks of the Troutdale Formation results from depositional conditions involving torrential, flood stage river flow. He says that where the bedding of the gravels can be determined, it dips to the south. The work of Trimble (1963), described below, discusses 
the attitude of the Troutdale Formation's rocks in greater detail. Hodge noted that non-marine fossil flora are present in the Troutdale Formation, while fresh and saltwater fossil fauna are absent.

In 1942, Treasher published an outcrop geologic map of the Portland, Oregon area. The geology within his map area has since been modified and refined somewhat, but he nevertheless set forth a solid framework, in terms of a base map, from which to proceed with further studies of the area.

As part of their 1944 publication on Pliocene floras of California and Oregon, Chaney, Condit, and Axelrod, reported on a floral collection of 1046 specimens, which were obtained from the basal contact zone of the Troutdale Formation at Buck Creek and Camp Collins. Their report states that these fossil leaves are early Pliocene in age.

In 1952, Lowry and Baldwin published a report on late Cenozoic geology of the lower Columbia River Valley in Oregon and Washington. Their abstract, pertaining to the Troutdale Formation, includes the following information. Erosion-modified, anticlinal highs developed in the rocks of the Columbia River Basalt Group, and the lower part of the Troutdale Formation was deposited in downwarps along the Columbia River, while similar sediments were deposited in tributary valleys. These events probably took place during early Pliocene time. In their section 
on Pliocene formations, Lowry and Baldwin state that, contemporaneous with and interbedded in part with the Pliocene stream deposits, of which the Troutdale Formation is a part, are basic volcanic rocks of the Rhododendron, Boring "agglomerate," "Cascan," and Boring Lavas formations. The Columbia River, they state, was the medium from which the Troutdale sands and gravels were deposited, as a result of a rise in base level which accompanied submergence in the region in Pliocene time. Furthermore, these workers state that the total thickness of the Troutdale Formation may have been nearly 610 meters in the Portland synclinal basin. These authors state that an angular unconformity separates the Troutdale sediments from the lavas of the Columbia River Basalt Group at Crown Point, and that the sediments here may be younger than those in contact with the basalt in the deeper portion of the Portland syncline, farther to the west. Finally, they recognize, as Williams did, that there is a basalt flow interbedded in the Troutdale Formation at Crown Point.

Trimble (1963) separated the lower beds of the Troutdale Formation, and named them the Sandy River Mudstone. Trimble said that the distinct difference in lithologic character and genesis between the Sandy River Mudstone and the Troutdale Formation is sufficient basis for separating them. Trimble defined the contact between the Sandy River Mudstone and the Troutdale Formation as the horizon where the parallel-bedded siltstone and claystone of the 
Sandy River Mudstone meet the lowermost coarse, lenticular sandstone and conglomerate of the Troutciale Formation. Trimble then states that the Sandy River viudstone underlies the Troutdale Formation, and that the Boring Lavas overlie the Troutdale Formation. Trimble's sedimentologic and petrologic observations, pertaining to the Troutdale Formation, include the following:

(1) The Troutdale Formation is commonly well indurated, and the clayey alteration constitutes the principal cement.

(2) Irregular-lenticular bedding, planar bedding, and cross-bedding are present in the Troutcale Formation.

(3) Cobbly pebble conglomerate appears to constitute the entire Troutdale Formation near the east edge of his map area in Clark County, Washington. These beds are exposed in the valley of Lawton Creek.

(4) The conglomerate is chiefly a poorly stratified pebble conglomerate, which is composed of as much as 30 percent quartzite.

(5) The quartzite pebbles are well rounded.

(6) Locally, as in Sec. 6, T.1 S., R.4 E., the Troutdale decosits contain micaceous, quartzose sandstone.

(7) In the western area of his map, there is micaceous arkosic sanastore.

(8) In the southern part of his map, the sandstone is commonly tuffaceous.

(9) The sandstone is well sorted, and locally contains minor amounts of muscovite and quartz. 
(10) In the eastern part of his map, the sandstone is largely a vitric sandstone, composed mostly of sideromelane grains.

(11) Grains in this sandstone are mostly coarse to very coarse sand size, although the sandstone is conglomeratic in places.

(12) Coverings of palagonite and clay surround the unaltered particles in this sandstone, which are of angular, black, fragmental glass.

(13) A layer of stratified fine sandstone, siltstone, and claystone is exposed along the Sandy River in the Camas quadrangle, and this stratum occurs about 30 meters above the Troutdale Formation's base. This is a persistent unit which locally contains leaves. This stratum is also exposed at the north end of the Stark Street Bridge.

(14) The upper contact of the Troutdale Formation is an erosional surface of considerable relief, upon which the Boring Lavas were extruded. Trimble's map also shows that in some areas, where the Boring Lavas are not present, Quaternary sediments are in contact with the Troutdale Formation.

(15) Bedding in the Troutdale Formation is almost horizontal, generally dipping less than $2^{\circ}$ to the west or southwest in the eastern part of his map area, to the north or northwest in the southern part of the area, and generally southward in the north-central part of the area. 
Howell (1957-1970) contributed field notes and maps which establish a previously undocumented fossil locality. At this locality above and south of Gordon Creek, Howell reports that the contact between the Sandy River Mudstone and the Troutdale Formation is exposed.

In 1975, Beeson, in collaboration with Johnson and Moran, published a report dealing with fault identification in the Portland area. Geochemical data on rocks of the Columbia River Basalt Group and Boring Lavas are contained in their report. The data forms a large part of the basis for the comparison and contrast with the geochemical data which was obtained on the basalt clast samples of the present report.

Beeson and Moran (1979) investigated the stratigraphy of the Columbia River Basalt Group in western Oregon. Necessary to their work was instrumental neutron activation analysis of Columbia River Basalt Group samples. Their geochemical information forms an important part of the basis for the geochemical analyses of the present report. Anderson (1980) states that quartzite-bearing conglomerate is interbedded between the Pomona and Frenchman Springs members of the Columbia River Basalt Group, approximately 9 kilometers west of Hood River, Oregon.

Tolan (1982) investigated the stratigraphy from Crown Point to Bridal Veil canyon. In the vicinity of Crown Point, Tolan noticed, as have previous workers, that a lava flow is intercalated with the Troutdale Formation. 
On the east side of Crown Point, along the old Columbia River Scenic Highway, the basal contact of the Troutdale Formation is exposed. Tolan states that the rocks which underlie the Troutdale Formation at this locality are basalts of a Priest Rapids intracanyon flow. Tolan also states that, just east of this contact, the rocks of the Skamania Volcanic Series, no younger than early Miocene, are exposed. Furthermore, Tolan reports that rocks of the Grand Ronde Basalt lie adjacent to these Skamania rocks, to the east. Tolan said that the Troutdale deposits in the Bridal Veil canyon show a westward channel direction, and that at least some of these deposits may be as old as 12 to 14 million years (Tolan, personal communication, 1982 ).

\section{LOCAL GEOLOGIC SETTING}

The oldest rocks exposed in the vicinity of the study area are basalts of the Skamania Volcanic Series. These rocks crop out along the old Columbia River scenic Highway at the eastern base of Crown Point, and are no younger than early Miocene in age (Tolan, 1982). Altered basaltic and andesitic volcanic rocks of the Skamania Volcanic Series are exposed east and north of Prune Hill (Trimble, 1963). The next oldest rocks are those of the Columbia River Basalt Group, which are middle Miocene in age, and are very widespread, occurring as far east as the Oregon-Idaho border (Swanson and others, 1979). Several members of three formations of the Columbia River 
Basalt Group have been recognized in the vicinity of the study area. The oldest of these rocks in the area are those of the Grand Ronde Basalt, which occur both west and east of Crown Point (Beeson, 1982, personal communication). Next oldest are the rocks of the Frenchman springs Member of the Wanapum Basalt, which crop out along the Sandy River at the mouth of Buck Creek. The basalts at Crown Point are those of an intracanyon flow of the Priest Rapids Member of the Wanapum Basalt. In the canyon of Bridal Veil Creek, rocks of the Pomona Member of the Saddle Mountains Basalt are exposed (Tolan, 1982).

During the uplift of the Cascade Range, large scale deformation of the rocks of the Columbia River Basalt Group took place, while local tectonism in the Portland area produced such major topographic features as the Tualatin, Chehalem, Cooper, and Bull Mountain anticlinal structures, and the Tualatin Basin (Schlicker and Deacon, 1967). Beeson, Johnson, and Moran (1975) report a complexly folded and faulted zone extending southeastward from, and aligned with the Portland Hills. Beeson and his colleagues (1975) found that major faulting of this zone trends N35W and includes the Portland Hills fault, a major right-lateral fault located along the eastern base of the Portland Hills. Beeson and others (1975) describe the Portland Hills as a complex anticlinal structure consisting of three subparallel folds. 
Locally, the upper surface of the Columbia River Basalt Group became deeply weathered and laterized (Trimble, 1963). Unconformably overlying the Columbia River Basalt Group and filling the willamette and Tualatin structural basins are lacustrine and fluvial sediments of lower Pliocene age (Trimble, 1963). These include laterized pebbly silt, clay, and sand of the Helvetia Formation, the Sandy River Mudstone and the Troutdale Formation (Schlicker and Deacon, 1967). The weathered sediments of the Helvetia Formation directly overlie basalt in the Tualatin Valley region where the sediments are considered to be correlative with the Sandy River Mudstone (Schlicker and Deacon, 1967). The sedimentary rocks of the Sandy River Mudstone and Troutdale Formation underlie the Portland area to a depth of about 520 meters (Lowry and Baldwin, 1952), while in the Tualatin Valley these sediments extend to a depth of about 460 meters (Schlicker and Deacon, 1967).

Intercalated with and overlying the Troutdale Formation are rocks of the Boring Lavas, which include basalt flows, tuff, breccia, cinder, and scoriaceous phases (Williams, 1916, Trimble, 1963). These rocks are prominently exposed at Mt. Norway, Prune Hill, Crown Point, Chamberlain Hill, Mt. Scott, Mt. Sylvania, Swede Hill, Mt. Tabor, Ross Mountain, and in other areas. In contact with the deposits of the Troutdale Formation and the rocks of the Boring Lavas are Plio-Pleistocene piedmont and terrace deposits (Trimble, 1963). These deposits consist of fluvially-derived 
gravel, mudflow, and debris-flow materials, and are named, from oldest to youngest, the Walters Hill, Springwater, Gresham, and Estacada Formations (Trimble, 1963). Widespread lacustrine and fluvial deposition occurred in the Willamette, Tualatin, and lower Columbia River valleys in late Quaternary time (Trimble, 1963). 
DATA PRESENTATION AND DISCUSSION

The following section presents the data derived from the various sampling and analyzing methods used in the present study to investigate the lithological characteristics of the Troutdale Formation in the study area. The data forms the basis for discussing answers to the fundamental questions concerning the sedimentary rocks of the Troutdale Formation in the study area. In review, the fundamental questions addressed are as follows: the provenance of the Troutdale rocks, the development of a representative composite section of the Troutdale Formation, the environment within which the sedimentary rocks of the Troutdale Formation were deposited, and the presence of granulometric and compositional trends within the Troutdale Formation.

\section{TROUTDALE LITHOFACIES}

Qualitative inspection of outcrops of the Troutdale Formation in the study area reveals that the Formation is composed predominantly of conglomerate and coarse-grained sandstone, with minor amounts of siltstone. All three of these lithofacies are exposed in the type locality, along the Sandy River, at the Stark Street Bridge. The appearances of the lithofacies here are typical of their 
appearances throughout the study area. From the Stark Street Bridge locality, a sample of the conglomerate lithofacies, and a sample of the coarse-grained sandstone lithofacies were subjected to sieve analysis. Figure 2 shows the sample localities. Sieve analysis of the siltstone lithofacies was not performed because of the siltstone's fine-grained nature, its limited exposure, and because of the difficulty involved in dissaggregating the rocks.

The histogram of the conglomerate lithofacies sieve analysis sample is shown in Figure 3 . The histogram of the coarse-grained sandstone lithofacies is shown in Figure 4. The cumulative size frequency curves for the conglomerate and coarse-grained sandstone lithofacies are shown in Figure 5. Table I summarizes the following parameters which were computed according to the procedures of Folk (1974) for each curve shown in Figure 5: $\mathrm{M}_{Z}, \sigma_{I}, \mathrm{Sk}_{I}$, $\mathrm{K}_{\mathrm{G}}$, where $\mathrm{M}_{Z}$ is the graphic mean, $\sigma_{\mathrm{I}}$ is the inclusive graphic standard deviation, $\mathrm{Sk}_{\mathrm{I}}$ is the inclusive graphic skewness, and $\mathrm{K}_{G}$ is the graphic kurtosis.

TABLE I

SUMMARY OF LITHOFACIES PARAMETERS

\begin{tabular}{|l|c|c|c|c|}
\hline Lithofacies & $\mathrm{M}_{\mathrm{Z}}$ & $\sigma_{\mathrm{I}}$ & $\mathrm{Sk}_{\mathrm{I}}$ & $\mathrm{K}_{\mathrm{G}}$ \\
\hline Conglomerate & -3.6 & 2.0 & +0.78 & 1.07 \\
\hline Coarse-grained Sandstone & 1.0 & 0.96 & +0.17 & 0.94 \\
\hline
\end{tabular}




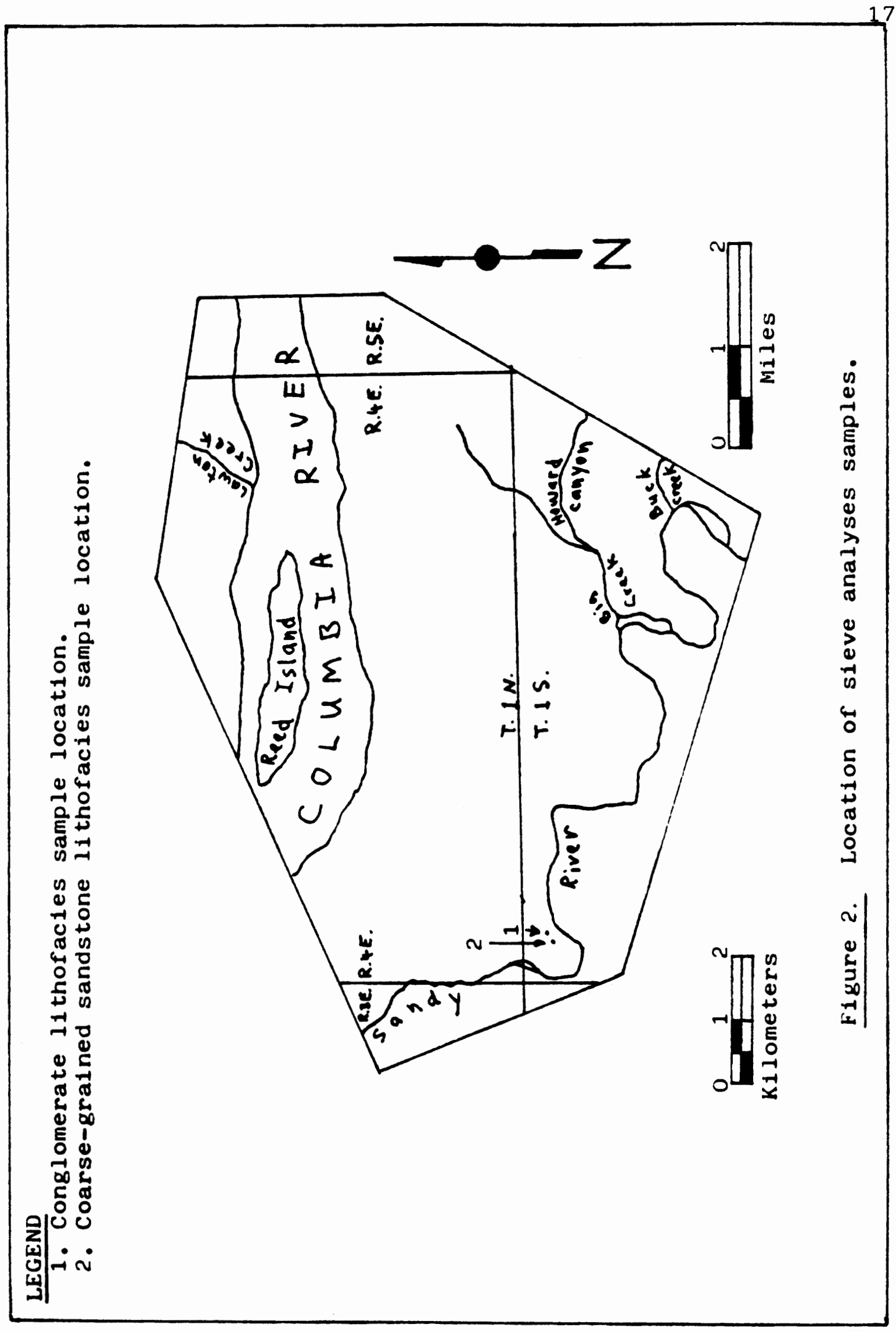




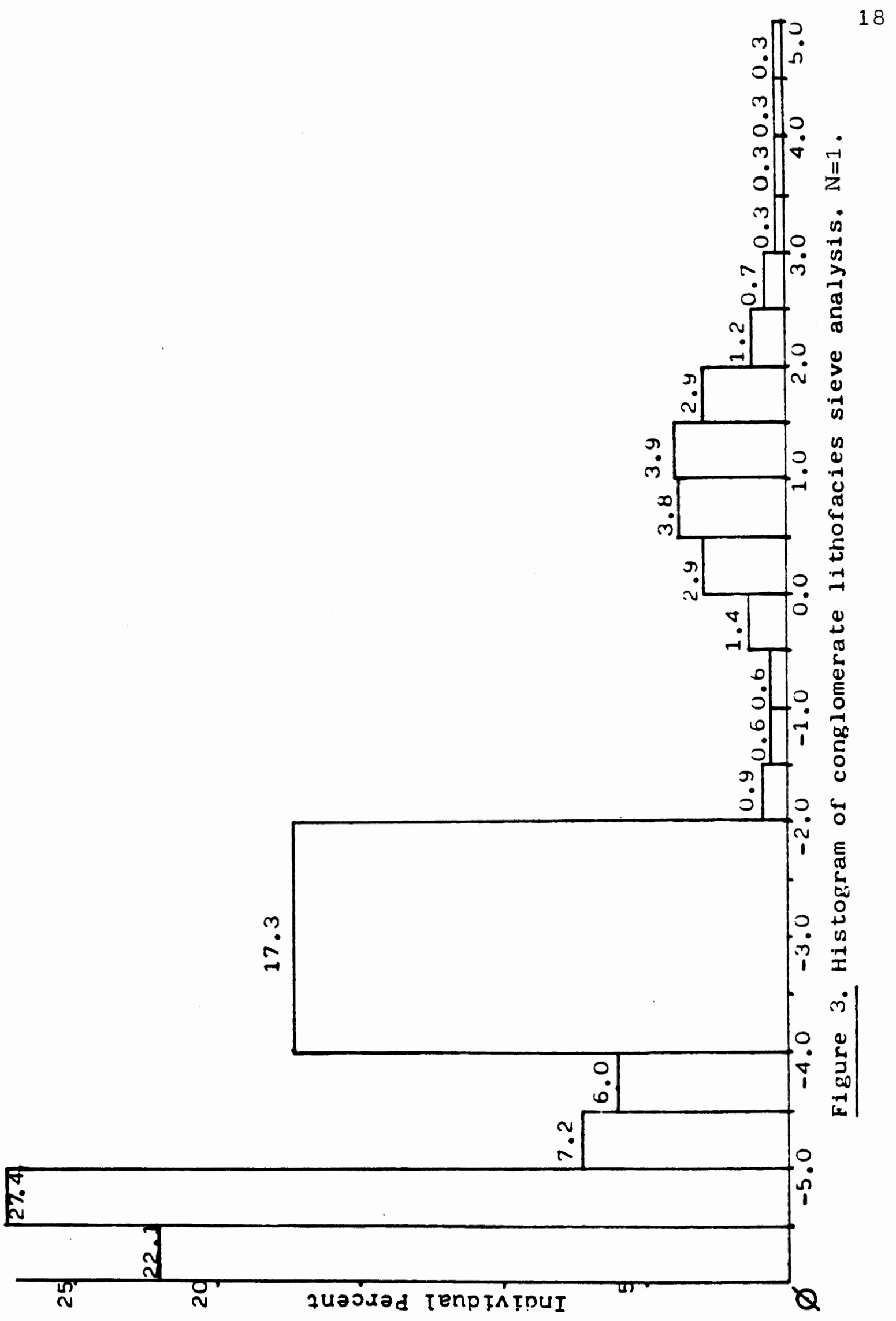




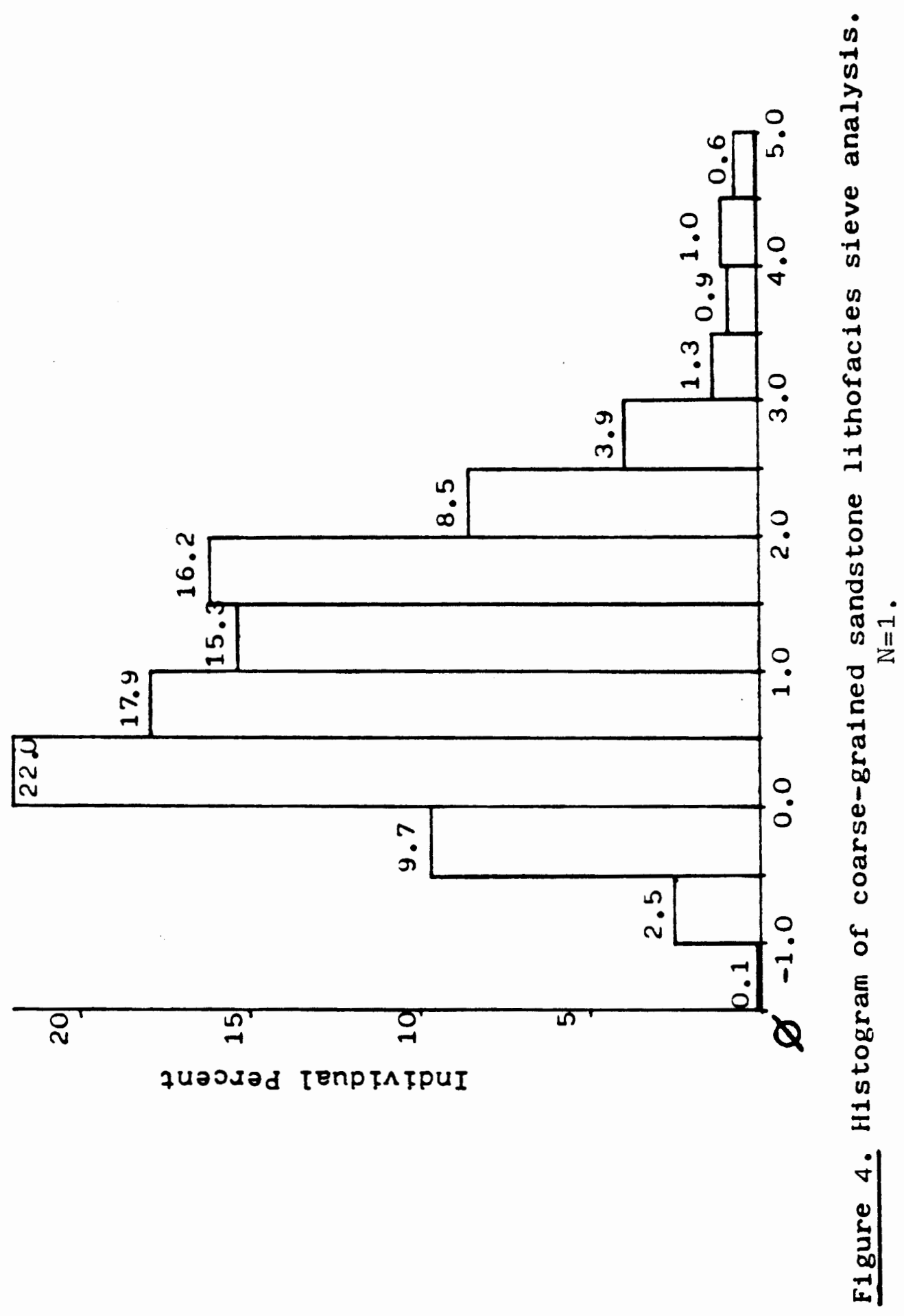




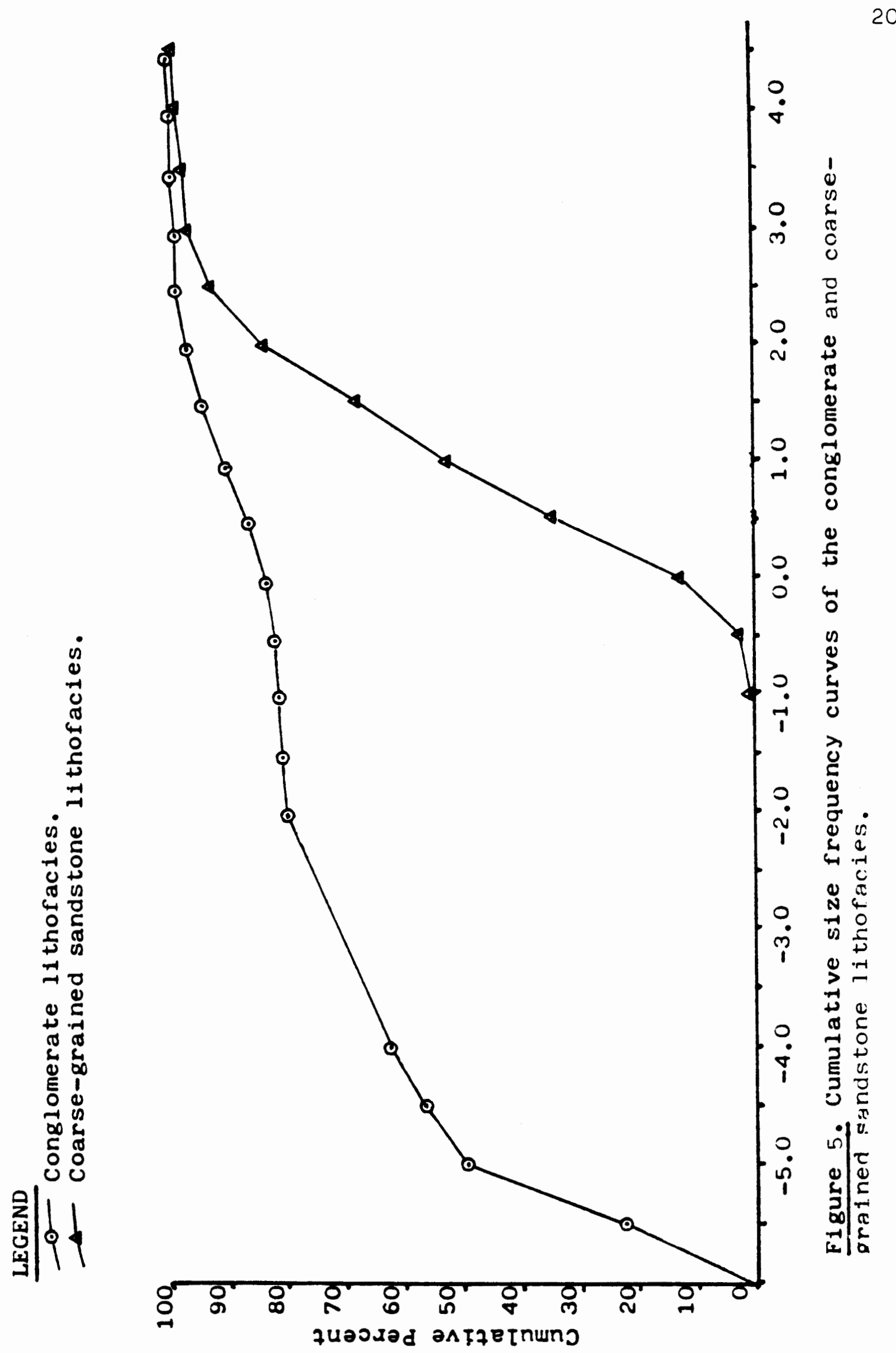


The sieve analyses show that the overall particle size of the conglomerate lithofacies $(-3.6 \emptyset=12.1 \mathrm{~mm})$ is much larger than that of the coarse-grained sandstone lithofacies $(+1.0 \emptyset=0.5 \mathrm{~mm})$. From Table I it is apparent that the Troutdale lithofacies are moderately to poorly sorted, especially the conglomerate.

In order to facilitate the study of the Troutdale Formation, it is considered in terms of the lithofacies mentioned above. In the field, the lithofacies were distinguished according to the following criteria.

\section{Conglomerate Lithofacies}

The conglomerate lithofacies consists of cemented gravel, in which the clasts over $2.0 \mathrm{~mm}$ in length are rounded to well rounded. The matrix is composed of angular to subrounded, fine to very coarse sand. Hydrochloric acid tests reveal that calcareous cement is not present. The cement apparently consists of clay minerals (Trimble, 1963). The conglomerate exhibits irregular-lenticular bedding, planar bedding, and planar cross-bedding. The volume proportion of gravel is variable, and where the bulk of the rocks changes from gravel to sand, the conglomerate grades into the coarse-grained sandstone lithofacies. Conglomerate beds are occasionally found underlying and overlying beds of both the siltstone lithofacies, and the coarse-grained sandstone lithofacies. 
Coarse-grained Sandstone Lithofacies

The coarse-grained sandstone lithofacies is composed of cemented sand, in which the grains are angular to subrounded. Most of the particles are medium to coarse sand $(0.25 \mathrm{~mm}$ to $0.50 \mathrm{~mm})$. Clay minerals are apparently responsible for the cohesion of the sandstone's particles (Trimble, 1963). The sandstone exhibits planar bedding, planar cross-bedding, and trough cross-bedding. Like the conglomerate, the gravel content of the sandstone is variable, and where the bulk of the rocks changes from sand to gravel, the sandstone grades into the conglomerate lithofacies. Beds of the coarse-grained sandstone lithofacies occasionally overlie and underlie beds of both the conglomerate lithofacies, and the siltstone lithofacies.

\section{Siltstone Lithofacies}

The siltstone lithofacies is composed of beds and laminae whose grain sizes range from medium sand to clay $(0.50 \mathrm{~mm}$ to less than $0.0039 \mathrm{~mm})$. The beds in the siltstone lithofacies exhibit planar bedding, planar cross-bedding, and trough cross-bedding. Fossil fauna of early Pliocene age (Chaney and others, 1944) are present in the siltstone lithofacies. Beds of the conglomerate and coarse-grained sandstone lithofacies are found both overlying and underlying beds of the siltstone lithofacies. 
MEASURED SECTIONS

In order to develop a representative composite section of the Troutdale Formation in the study area, ten sections were measured. These sections were chosen because of their accessibility, and because they cover the study area well, considering the lack of laterally continuous exposures in this area. The measured sections data also provide information regarding granulometric trends within the Troutdale Formation.

The locations of the measured sections are shown in Figure 6. Sections 1 and 2 were measured directly, using climbing equipment and a graduated tape. Due to the inaccessible nature of the tops of the other eight sections, as well as the danger of hazardous rockfall, the remainder were measured using a combination of visual inspection and estimation, and topographic map interpretation. The thickness of each of the three lithofacies was measured at each section locality.

The data on the measured sections is given in Table II. Table III lists the section numbers, their top and bottom elevations, and their thicknesses. Figure 7 provides an explanation of the units shown in Figure 8, which is a correlation chart of the ten sections. From Table II, it is apparent that well over half ( 56 to 60 percent) of the Troutdale Formation's exposures in the study area are composed of the conglomerate 


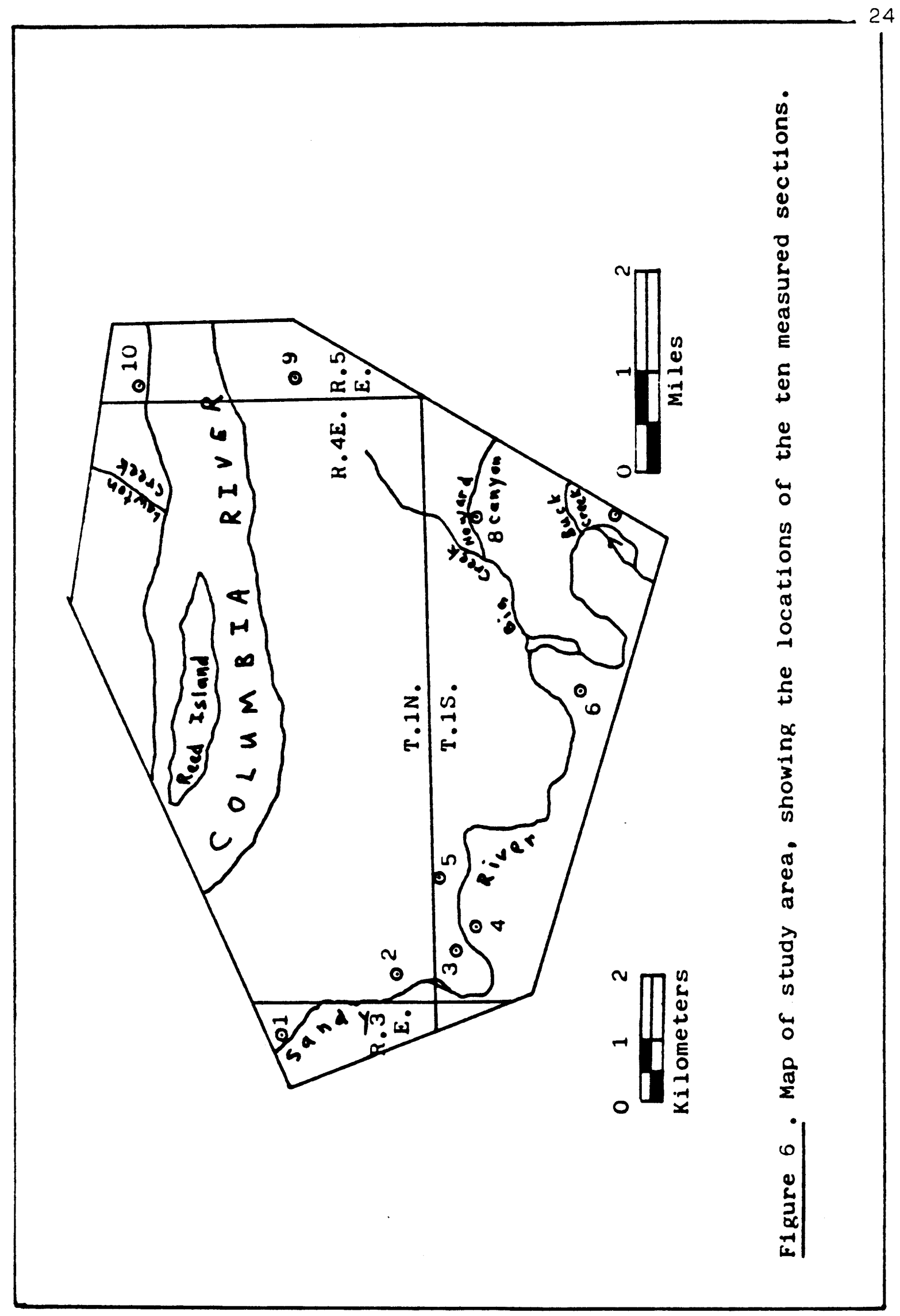




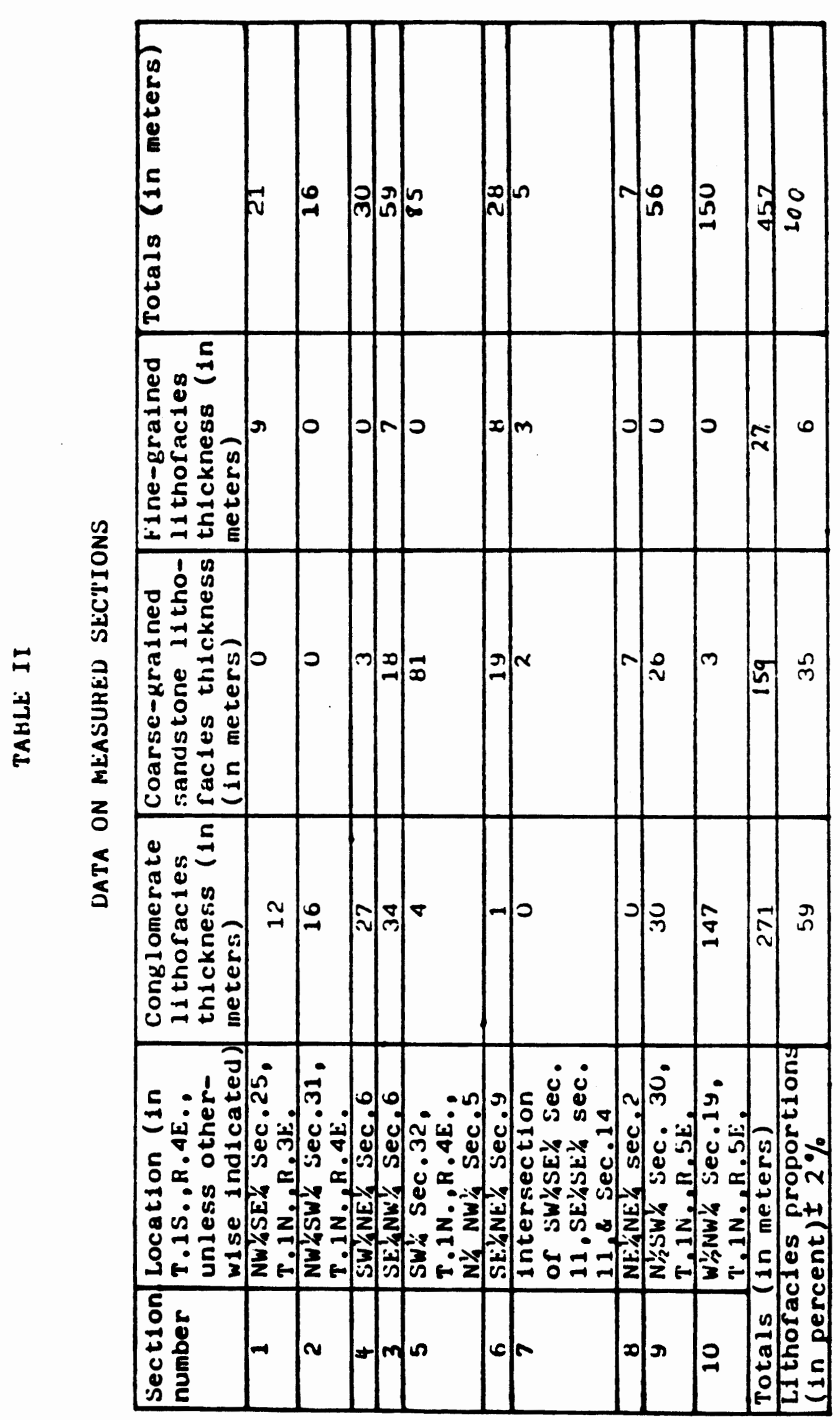




\section{TABLE III}

BASE ELEVATIONS, TOP ELEVATIONS, AND THICKNESSES

OF THE MEASURED SECTIONS

(Elevations in meters above sea level)

\begin{tabular}{|c|c|c|c|}
\hline $\begin{array}{c}\text { Section } \\
\text { Number }\end{array}$ & $\begin{array}{c}\text { Base } \\
\text { Elevation }\end{array}$ & $\begin{array}{c}\text { Top } \\
\text { Elevation }\end{array}$ & Thickness \\
\hline 1 & 9 & 30 & 21 \\
\hline 2 & 17 & 33 & 16 \\
\hline 3 & 10 & 69 & 59 \\
\hline 4 & 23 & 53 & 30 \\
\hline 5 & 46 & 131 & 85 \\
\hline 6 & 37 & 65 & 28 \\
\hline 7 & 98 & 103 & 5 \\
\hline 8 & 161 & 168 & 7 \\
\hline 9 & 226 & 282 & 56 \\
\hline 10 & 7 & 157 & 150 \\
\hline
\end{tabular}

Qal Alluvium

Qe Estacada Formation

QTb Boring Lavas

0.0 .0 .0
0.0 .0 .0
0.0 .0 .0 Conglomerate Lithofacies

$\because \because \because \because$ Coarse-grained Sandstone Lithofacies

Troutdale Eormation $(\mathrm{T} t)$

$E=--1$ Fine-grained Sandstone Lithofacies

Tsr

Sandy River ludstone

Tcr Columbia River Basalt Group

Figure 7. Explanation of units shown in Figure 8. 


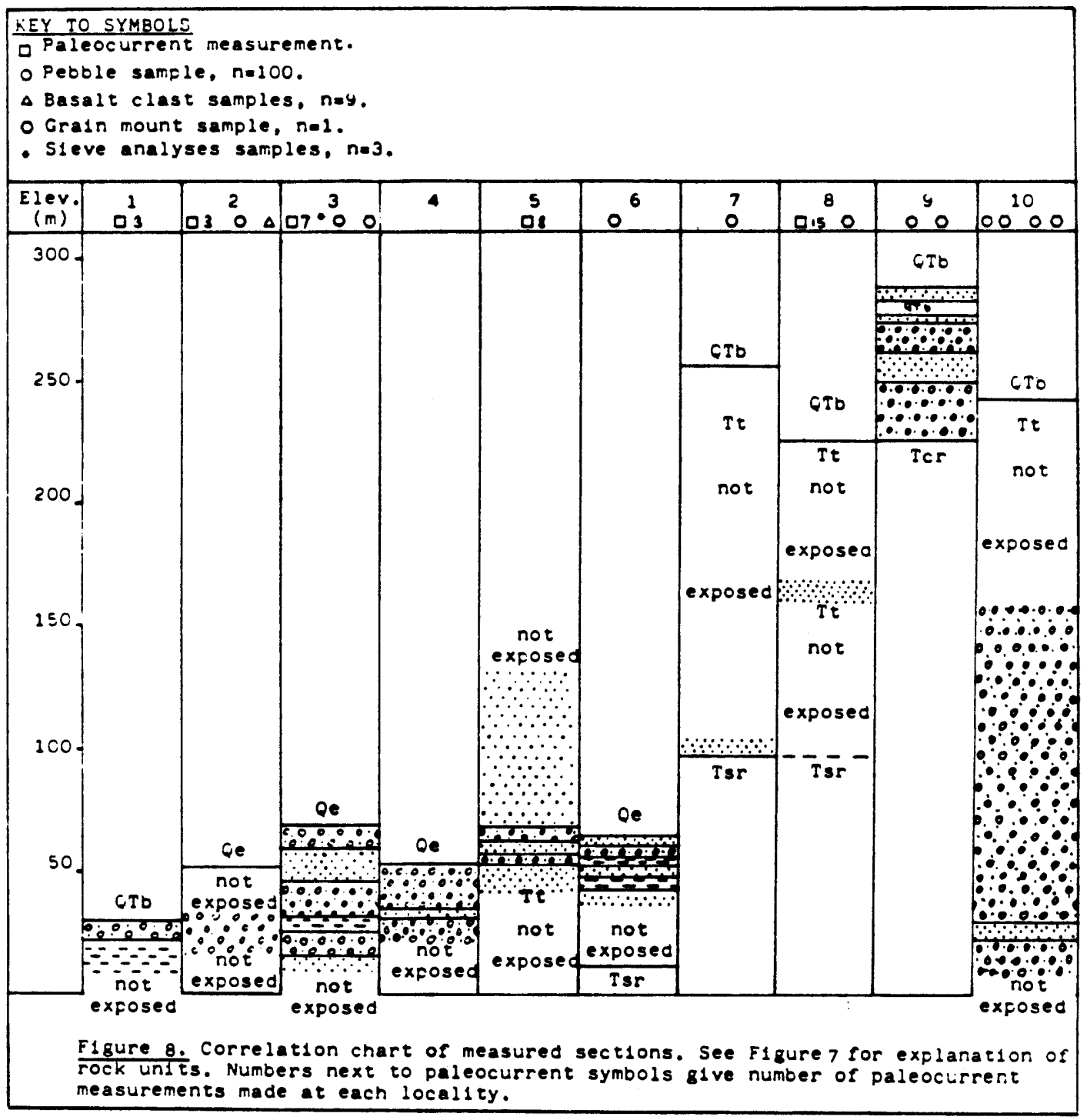


lithofacies. The coarse-grained sandstone lithofacies composes 34 to 38 percent of the Troutdale Formation's exposures. The siltstone lithofacies forms a minor portion of the exposures ( 4 to 8 percent).

From Figure 8, it can be seen that, except for section number 10, the basal contact of the Troutdale Formation occurs at higher elevations with increasing distances toward the east. This observation is consistent with the findings of Allen (1932, 1979), which is that the Troutdale Formation is exposed at higher elevations, the farther east one goes in the Columbia River Gorge. Figure 8 also shows that all possible lithofacies contact relationships are present. In addition, Figure 8 shows that the thickness of the Troutdale Formation as a whole varies with location. This points out that, from a grain size consideration, no simple sedimentologic trends, such as coarsening-upward, are apparent in the Troutdale Formation in the study area.

Within the study area, a representative composite section of the Troutdale Formation can be described. This section is a synthesized stratigraphic column which illustrates the relative proportions of lithofacies and their generalized sequences and contact relationships. Figure 9 illustrates the composite section. The composite section is composed almost entirely of beds of the conglomerate and coarse-grained sandstone lithofacies. In a vertical sequence, beds of the conglomerate lithofacies occasionally 
alternate with beds of the coarse-grained sandstone lithofacies. The thicknesses of these beds are seldom constant in any outcrop, since, as mentioned above, these two lithofacies occasionally grade into each other. Beds of the siltstone lithofacies are present adjacent to the Sandy River at measured section localities numbers 1,3 , and 6 (Figures 6 and 8 ). Beds of this lithofacies are not exposed anywhere else in the study area. Based on Trimble's work (1963) and the information of the present report, the sedimentary rocks of the Sandy River Mudstone apparently underlie the Troutdale Formation in the area adjacent to the canyon of the Sandy River. However in the vicinity of Crown Point, at measured locality number 9, the rocks of the Columbia River Basalt Group underlie the Troutdale Formation. Throughout much of the study area, such as at localities number $1,2,5,7,8$, and 10 (Figures 6 and 8 ), erosion and vegetation has covered the upper contact of the Troutdale Formation. In other areas, such as at localities numbers $2,3,4$, and 6 , deposits of the Estacada Formation overlie the Troutdale rocks.

Although not mapped, deposits of the Estacada or Gresham Formations are in contact with the Troutdale Forma-

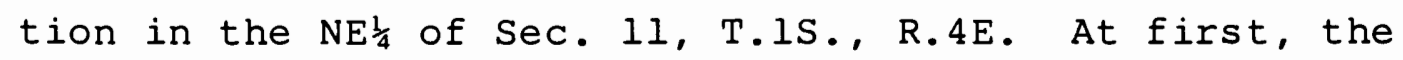
appearance of this outcrop is very similar to that of the conglomerate lithofacies. Close inspection of this outcrop, however, reveals that the deposits are not those of the Troutdale Formation's conglomerate lithofacies. 


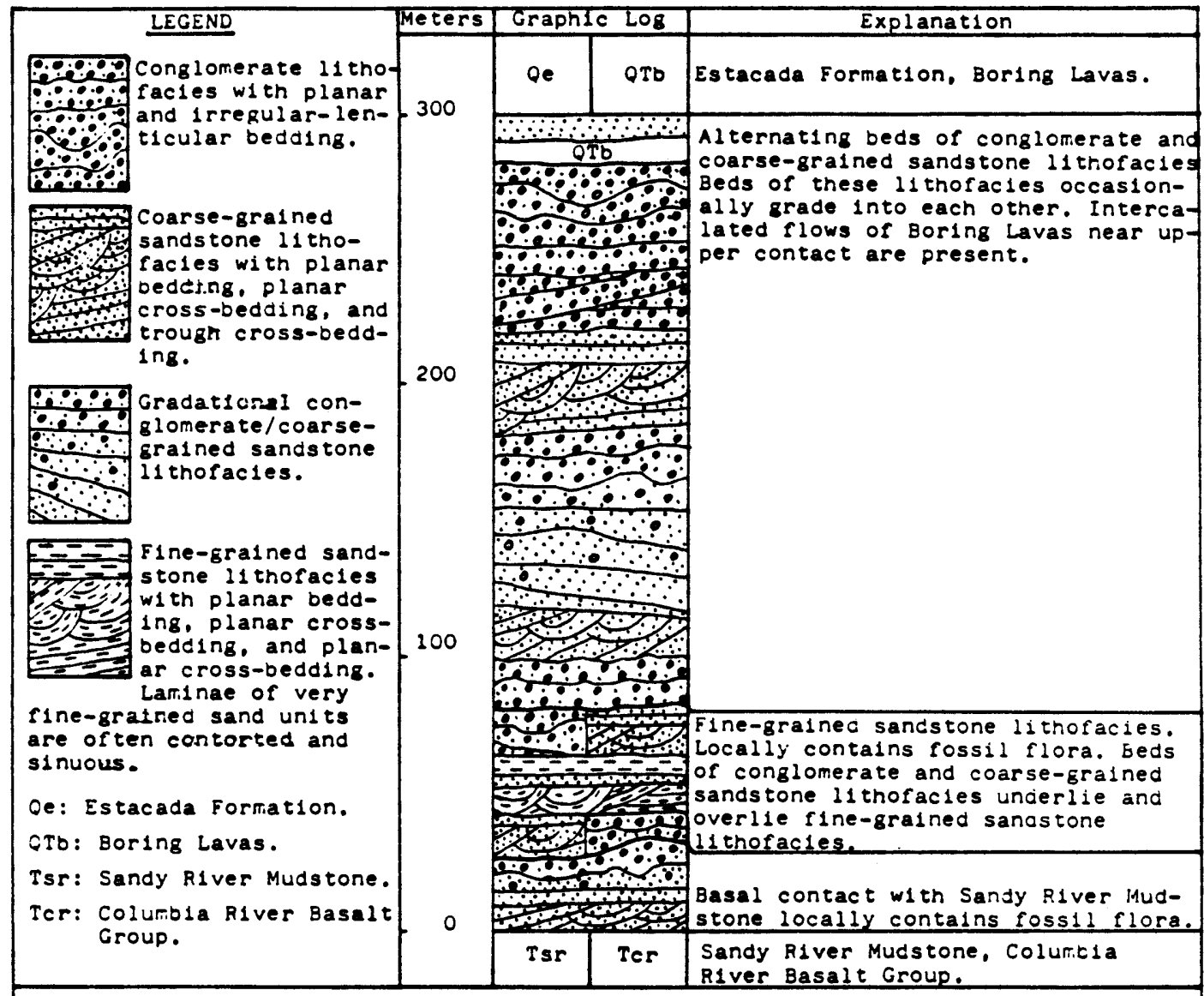

Figure 9. Representative composite Troutdale section. Scale at left relates 11thology to approximate formation position in meters above the formation's base. Maximum composite section thickness about 300 meters. Maximum exposed thlcknesses vary from 0 to 150 meters in the study area. See text for detalled discission on the formation's local characteristics. 
The deposits of this outcrop lack the high degree of cementation characteristic of the Troutdale rocks. The outcrop also has a relatively high andesite clast to basalt clast ratio (approximately 1 to 1 ), which is quite atypical of the conglomerate lithofacies (maximum andesite clast to basalt clast ratio is 0.13 to 1 , Table II). According to Trimble's (1963) criterion of topographic position, these deposits are those of the Estacada or Gresham Formation.

Throughout the rest of the study area, such as at localities numbers $1,7,8,9$, and 10 , rocks of the Boring Lavas overlie the Troutdale Formation. On the west side of Crown Point, in the vicinity of section number 9, rocks of the Boring Lavas are intercalated within the Troutdale Formation. The base of this lava exhibits a conspicuous baked zone against the underlying Troutdale conglomerate.

In the vicinity of measured section number 10 , measurements were made on an outcrop of the conglomerate lithofacies which exhibits irregular-lenticular bedding. The measurements allowed the calculation of the outcrop's bed relief index (BRI). The BRI is a measure of a bed's departure from a plane. The greater the irregularity of the bedding plane, the greater the BRI. Smith (1970) defined BRI as:

$$
B R I=\frac{2\left(\left(T_{1}+\ldots T_{n}\right)-\left(t_{1}+\ldots t_{n}\right)\right) \pm T_{e l} \cdot T_{e 2}}{L} \times 100,
$$


where $\left(\mathrm{T}_{1}+\ldots \mathrm{T}_{n}\right)$ is the sum total elevation of all relative high points between adjacent lows, $\left(t_{1}+\ldots t_{n}\right)$ is the sum total elevation of relative low points between adjacent highs, $L$ is the bed's horizontal traverse length, and $\mathrm{T}_{\mathrm{el}}, \mathrm{T}_{\mathrm{e} 2}$ are the heights of the extreme ends of the traverse. If either extreme end adjoins a "low," the value is added; if it is a "low" adjoining a "high," it is subtracted. Figure 10 illustrates the outcrop and the calculation of its BRI. A horizontal line was inscribed with the pick end of a rock hammer into the outcrop. The elevations of the highs and lows in Figure 10 are in meters above the horizontal datum. The outcrop exhibits a BRI of 12.1. Smith's (1970) study of the South PlattePlatte River shows a range of BRI values of 1.4 to 5.3 . Cross-section profiles of the White River yield a range of BRI values of 4.8 to 13.7 (Fahnestock, 1963).

\section{PETROGRAPHY}

The petrography section presents and discusses the data derived from three sampling and analyzing methods, in terms of the provenance of the sedimentary rocks of the Troutdale Formation. The first method involves pebble counts performed on clasts which were derived from exposures of the conglomerate lithofacies. The second method deals with instrumental neutron activation analysis (INAA) of basalt clasts sampled from one outcrop of the conglomerate lithofacies. The third method involves grain mount 


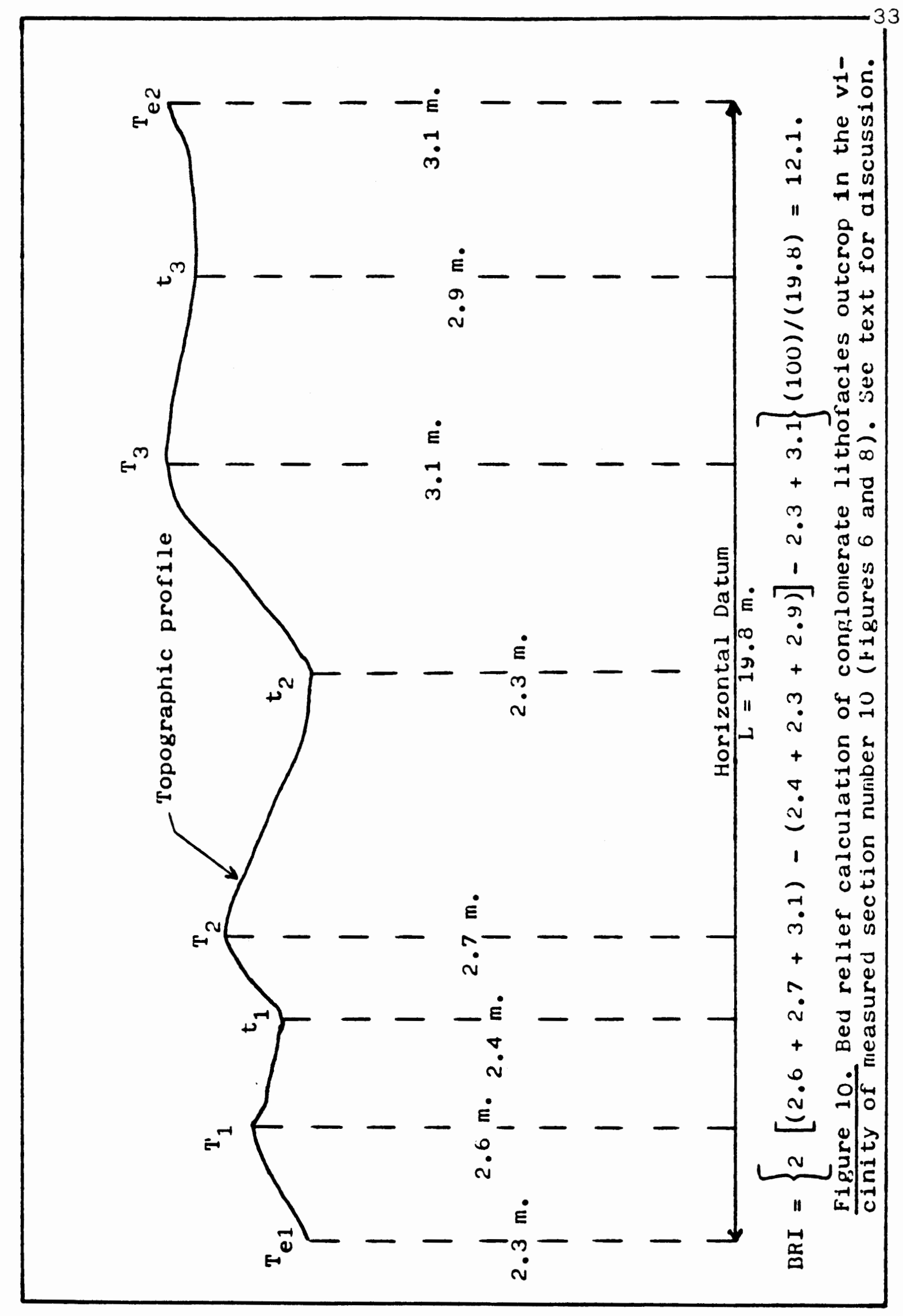


petrography of clastic particles derived from both the conglomerate and the coarse-grained sandstone lithofacies.

\section{Pebble Counts}

At each of five localities, 100 pebbles were collected. Figure 11 illustrates the locations from which these pebble samples were derived. Note that localities 1 through 3 correspond respectively with the following measured sections: 2, 3, and 9. Pebble sample localities 4 and 5 are included in the area in which measured section number 10 is located. The pebbles ranged in size from $36 \mathrm{~mm}$ to $64 \mathrm{~mm}$ in length. Pebbles of this size range were chosen because they are abundant in every outcrop which exposes the conglomerate lithofacies. Because of this, it is assumed that the estimates of the rock type distribution at the sample localities, which the analysis of these pebble samples provides, are representative of the entire conglomeratic portion of the Troutdale Formation at the sample localities, and this includes a range in clast sizes from pebbles to boulders $(4 \mathrm{~mm}$ to over $256 \mathrm{~mm}$ in length, respectively).

At each sample locality the following procedure was used. A square meter grid, divided into 100 equal parts, was inscribed on the outcrop. The surface of the outcrop was scraped off until a pebble was exposed in each $10 \mathrm{~cm}$ subsection of the square meter grid. Each pebble was broken open to reveal a fresh rock surface. 


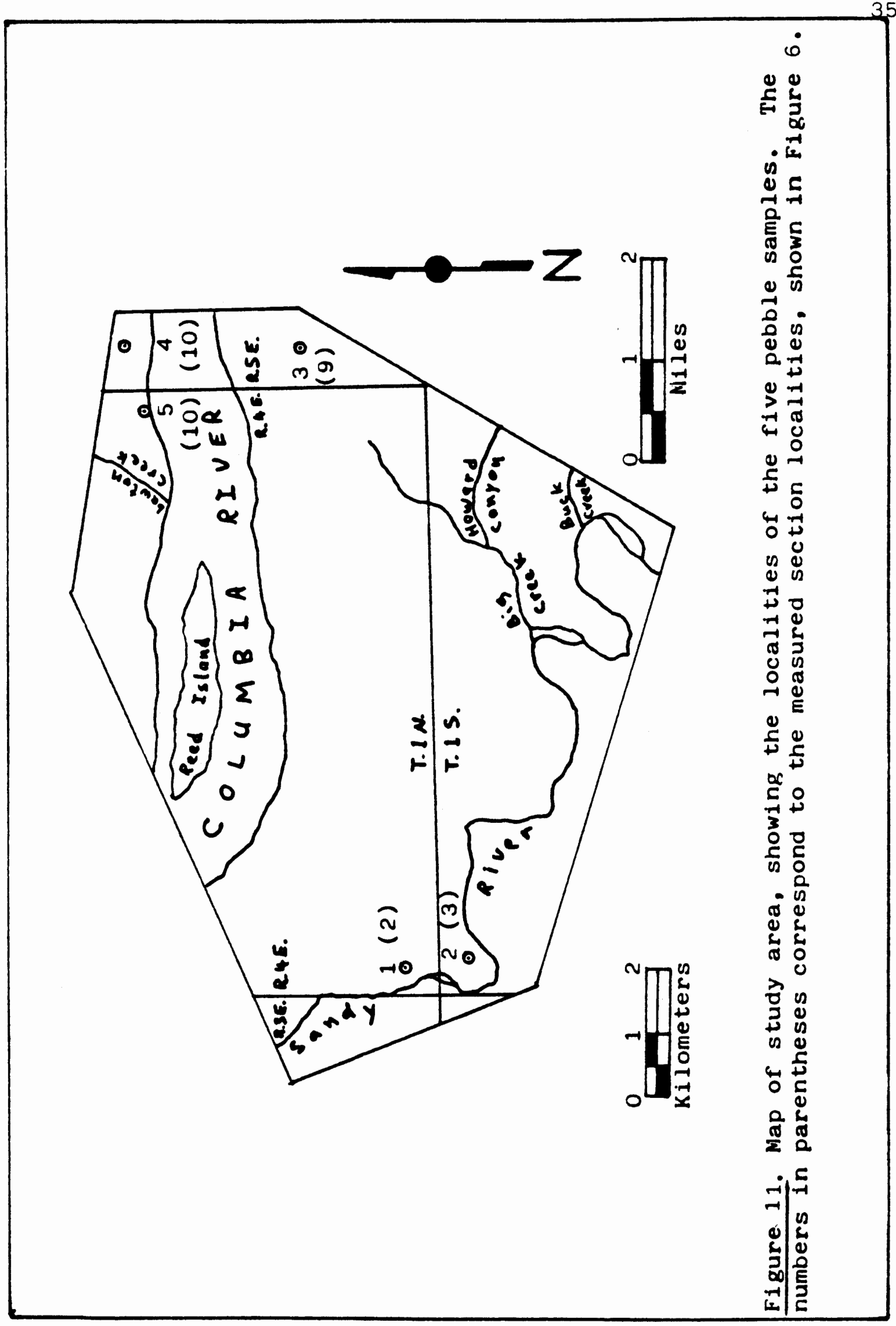


Then each pebble was identified in hand sample under a $12 \mathrm{x}$ hand lens, as to rock type. For a given rock type, each repetition of this procedure resulted in the total count for that rock type at that locality increasing by one. Since each sample contains 100 identified pebbles, the number of pebbles identified for each rock type represents an estimate of the percentage of that rock type in the Troutdale Formation at the sample locality.

Table IV summarizes the pebble count data and includes the following information: (1) sample locality numbers, which correspond to those shown in Figure 1l, (the numbers in parentheses refer to the corresponding measured section numbers), (2) map locations of the sample localities, (3) positions within the Troutdale Formation from which the samples are derived, (4) percentages of rock types in the Troutdale Formation at the sample localities, and (5) grand average composition.

To aid in making color determinations, the GSA RockColor Chart was used (The Geological Society of America, 1975). The five rock types identified in this pebble count were distinguished in hand sample, according to the following petrographic characteristics:

(1) Basalt - Medium dark gray (N4) to black (Nl), occasionally weathered to dark reddish brown (lOR 3/4), aphanitic to porphyritic-aphanitic.

(2) Andesite - Light gray (N7) to medium gray (N5), porphyritic-aphanitic. 


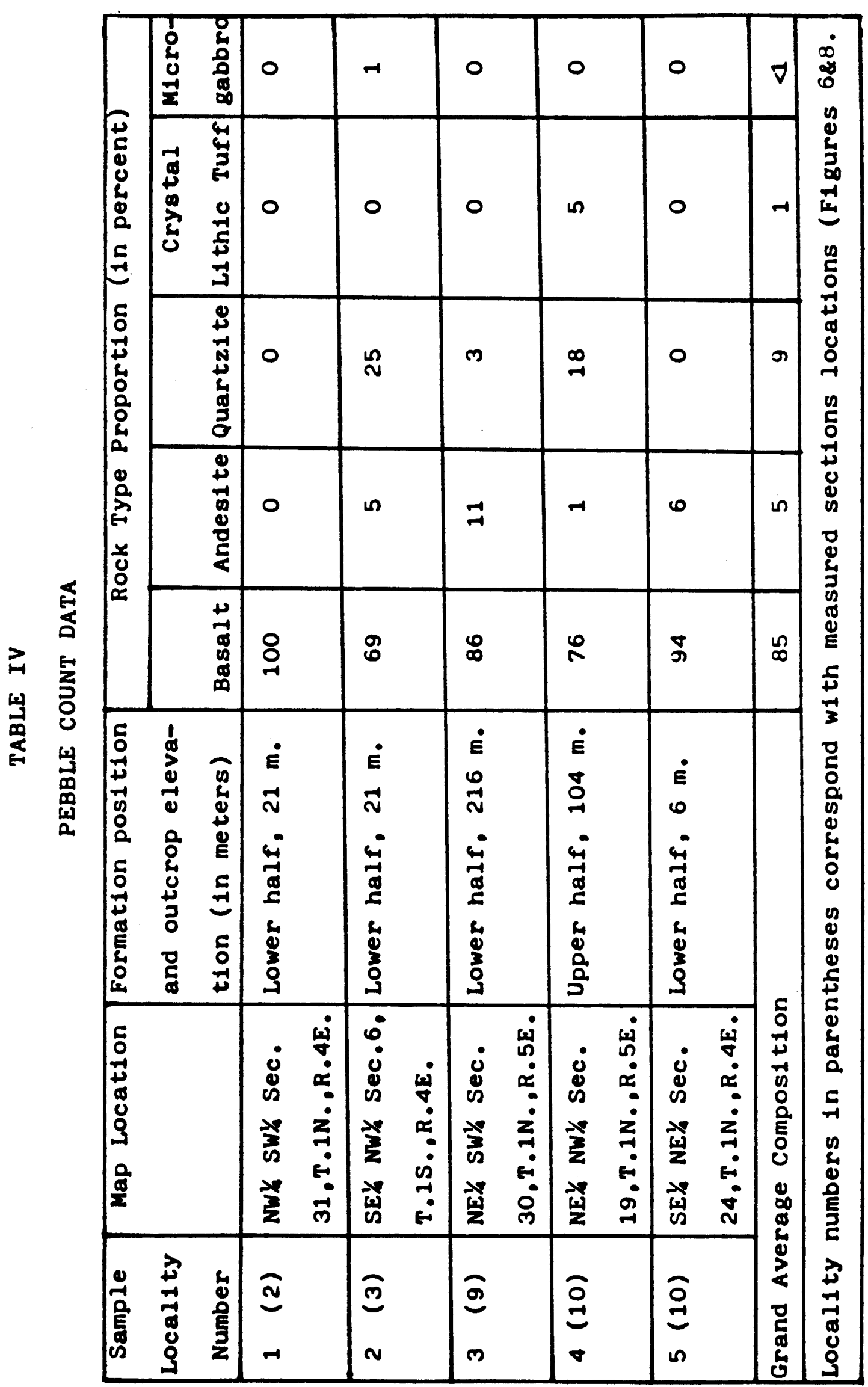


(3) Quartzite - Mono to polychromatic, aphanitic to phaneritic (crystals up to $1 \mathrm{~mm}$ in length), occasionally with polychromatic relict bedding banding.

(4) Crystal lithic tuff - Polychromatic, porphyriticaphanitic, occasionally with stretched grain borders, and phenocrysts up to $2 \mathrm{~mm}$ in length.

(5) Microgabbro - Dark gray (N3) to black (N1), mediumgrained ( $\frac{1}{2} \mathrm{~mm}$ in length).

These petrographic characteristics cover the range of the clasts examined in this pebble count. These petrographic characteristics do not necessarily cover the range of all clasts present in the Troutdale Formation. For example, there may be quartzite clasts present in the Troutdale Formation in which crystals are larger than $1 \mathrm{~mm}$ in length. Plutonic and vein quartz are present in the Troutdale Formation. All quartz pebbles were counted as quartzite in order to emphasize the presence of distal sources. The petrographic characteristics listed above, however, were sufficient to allow the pebble samples to be identified and analyzed.

As the data in Table IV show, basalt is the dominant rock type at every sample locality. Nowhere does its representation fall below 69 percent. Quartzite follows basalt as the next most abundant rock type. The proportion of quartzite attains a maximum of 25 percent at pebble sample locality number 2. Locality number 2 is the only place where a rock of microgabbroic texture and composition 
was found. Only locality number 4 contains crystal lithic tuff clasts. The data were combined to yield an average composition according to the following procedure. The percent representation for each rock type was added, over the five localities, and the sum obtained was divided by 5 and rounded to the nearest whole percent. It is apparent then, from Table IV, that basalt accounts for the vast majority of the clasts over the five sample localities with an average representation of 85 percent. Quartzite is the next most abundant rock type with an average representation of 9 percent. The average representations of andesite and crystal lithic tuff are, respective$1 y, 5$ percent and 1 percent. One clast out of 500 was identified as microgabbro. Its representation is therefore less than 1 percent. There are no studies that deal with the sediments of the Troutdale Formation which indicate that the proportions of rock types present in the $36 \mathrm{~mm}$ to $64 \mathrm{~mm}$ size fraction of the conglomerate lithofacies are significantly different than the proportion of rock types present in other size fractions. Because of this, it is assumed that the pebble sampling method described above, yields valid estimates of the rock type distribution at the sample localities for the gravel fraction of the Troutdale Formation, which includes clast sizes from $4 \mathrm{~mm}$ to over $256 \mathrm{~mm}$ in length. Because basalt is the dominant rock type in the pebble samples, and because pre-Troutdale basaltic rocks are abundant in this area, 
it seems certain that at least some of the basalt in the pebble count samples represents proximal sources. At pebble sample locality number 2 , the representation of quartzite attains 25 percent. Allen (1932) has stated that in some places, the representation of quartzite is as high as 30 percent. He attained this figure in Bridal Veil Canyon (Allen, 1982, personal communication). Allen used a channel sampling method to obtain his pebbles at this locality which is out of the present study area to the east. He feels that any discrepancy between the maximum quartzite content obtained in his and the present study may be due to both the location and the sampling method (Allen, 1982, personal communicaton). Regardless of any such discrepancies, the pebble count data shows that quartzite forms significant amounts of the gravel fraction of the Troutdale Formation at the sample locations. Since pre-Troutdale quartzite source regions are located no closer than north eastern Washington, the presence of quartzite shows that distal sources played significant roles in supplying material to the Troutdale Formation.

\section{Instrumental Neutron Activation Analysis}

Nine cobble-size clasts ( $64 \mathrm{~mm}$ to $256 \mathrm{~mm}$ in length), derived from measured section number 2 (Figures 6 and 8), were subjected to instrumental neutron activation analysis. These clasts were identified in hand sample as basalt, and compared geochemically with a standard, 
BCR-1. The analyses of these nine basalt clasts yielded elemental abundances of a total of seventeen major and trace elements in each of the basalt clast samples. The data for these nine samples and the standard are given in the Appendix. Table $V$ presents the parent rock type determinations for the nine samples. The sample numbers of Table $\mathrm{V}$ correspond with those of the Appendix. These parent rock type determinations are courtesy of Beeson (1979, written communication). These determinations show that at least one formal member and two informal members of the Columbia River Basalt Group were sources for the sedimentary rocks of the Troutdale Formation in the study area. This information also shows that rocks of the Boring Lavas or similar lavas were sources which contributed material to at least the upper part of the Troutdale Formation.

Although the basalt clasts were cobble-size, it is reasonable to assume that these basalt types are present in the entire range of clast sizes in the conglomerate lithofacies of the Troutdale Formation in the study area. Since the rocks of the Columbia River Basalt Group are very widespread, they may have served as distally-located sources. However, this geochemical information corroborates the notion mentioned above in the pebble-count section, that the rocks in the Columbia River Basalt Group were proximal sources. The geochemical information also shows 
TABLE V

GEOCHEMICAL PARENT ROCK-TYPE DETERMINATIONS

OF BASALT CLAST SAMPLES

\begin{tabular}{|c|c|}
\hline $\begin{array}{c}\text { Sample } \\
\text { Numbers }\end{array}$ & $\begin{array}{c}\text { Parent Rock-Type } \\
\text { Determinations* }\end{array}$ \\
\hline 7 & Boring Lavas \\
\hline 1,4$), 6,8$ & Frenchman Springs \\
\hline 3,5 & Grande Ronde (High Mg) \\
\hline 2,9 & Grande Ronde (Low Mg) \\
\hline *Parent rock-type determinations are courtesy \\
of Beeson (personal communicaton) Sample \\
numbers correspond with those of Appendix. \\
\hline
\end{tabular}

that extrusion of the Boring Lavas or similar lavas began, prior to the cessation of Troutdale deposition.

\section{Grain Mount Petrography}

Samples of the coarse-grained sandstone lithofacies and samples of the matrix material from the conglomerate lithofacies were collected from ten localities and analyzed under a petrographic microscope. The map shown in Figure 12 illustrates the localities from which these ten petrographic samples were derived. Note that samples 1 and 2 correspond with measured section number 10, while samples $4,5,6,8$, and 10 correspond respectively with measured sections numbers $6,3,8,7$, and 9 .

Using the pick end of a rock hammer, sandstone and conglomerate matrix materials were scraped off the outcrop into a plastic bag. The samples were then taken back to the lab where they were washed in a 250 mesh sieve, in order to remove most of the fine, clay-size particles, and then dried in an oven. Once dry, the samples were 


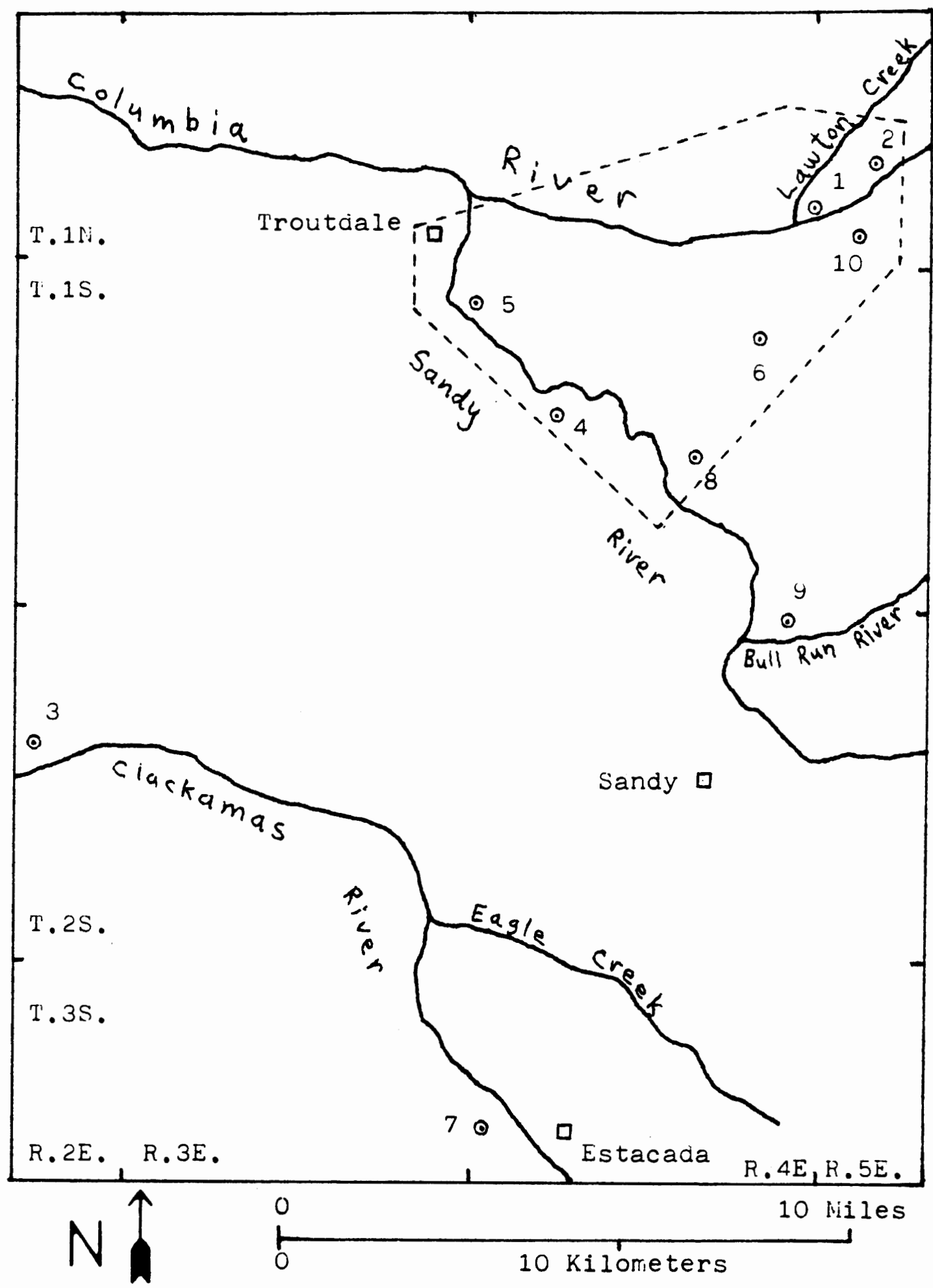

Figure 12. Sketch map of region, showing the locations of the ten grain mount samples. The study area is outlined. 
sieved between 100 and 20 mesh screens, in order to provide a convenient range in grain size. The utility of the grain sizes is discussed in the next paragraph. Once the grains were glued to slides, they were ground down to thin section proportions ( 30 - 35 microns). The samples were then scanned under a petrographic microscope in order to identify the components present. The samples were then stained for potassium and plagioclase feldspar, in order to distinguish between the two. Finally, after staining, the samples were line counted.

This grain mount petrography concentrated on the identification of rock fragments, rather than doing a complete petrographic analysis, for two basic reasons. First, for any given identified grain, a rock fragment provides more information, in general, about the source rocks, than a single mineral. Secondly, since most of the fine silt- and clay-size particles were elimianted, the optical clarity of the remaining sample is noticeably enhanced, thereby facilitating the identification and counting of the samples' sand size components. Referring to Figure 4, and keeping in mind that the grain mount samples were sieved between $2.8 \emptyset$ and $0.26 \emptyset$ screen openings, it is apparent that the vast majority (over 87 percent) of the particles in the samples were subjected to petrographic analyses. This analytical procedure provides provenance information on essentially all significant components (R.O. Van Atta, 1982, personal communication). 
Table VI lists the sample numbers which correspond with those shown in Figure 12, the lithofacies from which the samples were derived, and the localities of the samples. Table VII summarizes the line counting results which were based on 300 identified grains per sample. In order to facilitate rapid line counting, all volcanic rock fragments were grouped together, rather than attempting to interpret and count more detailed groupings, such as silicic, intermediate, and mafic volcanic rock fragments. Any attempt to discriminate such detailed groups could be misleading. For example, a rock fragment whose overall appearance indicates it is a mafic volcanic rock fragment could actually be an intermediate volcanic rock fragment with feldspar and/or pyroxene grains broken off and missing. Since it is rare that large bodies of rock are composed entirely of one mineral, it is assumed that the single minerals counted in this grain mount analysis originally came from polynineralogic rocks. For example, the many plagioclase grains counted in this analysis are assumed to have originally been parts of larger rock masses, such as volcanic lava flows. In order to facilitate provenance determinations, rock fragments containing $\mathrm{K}$-spar were counted in the same category as single K-spar mineral grains. No $\mathrm{K}$-spar-bearing sources are present in proximal locations. Thus, the presence of K-spar, either as single minerals, or as part of rock fragments, indicates distal sources. The same procedure was applied to orthopyroxene and 


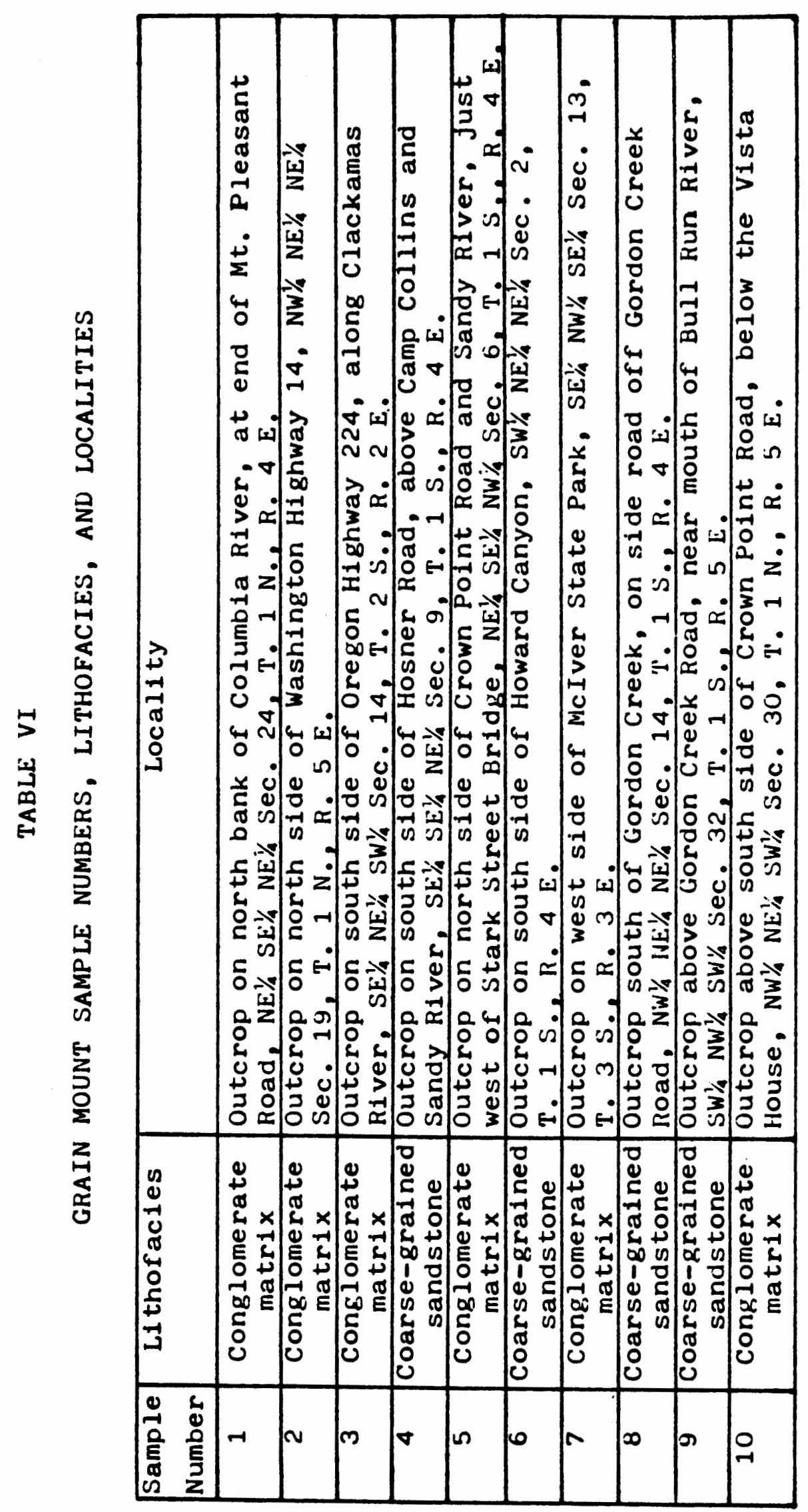




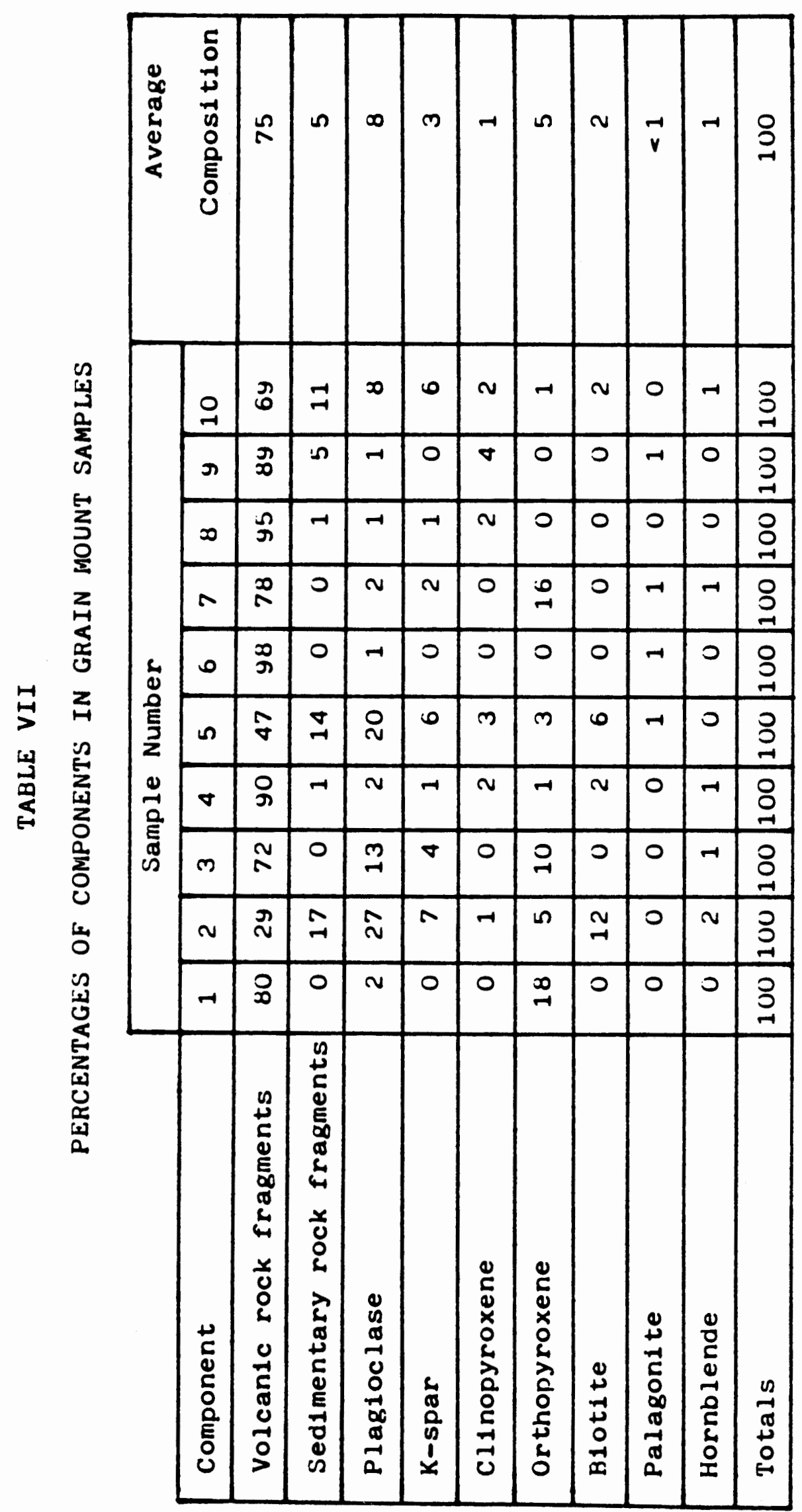


hornblende. Since it was found that clinopyroxene forms a common mineral in many rock fragments, it was counted only as separate mineral grains. This is also true for plagioclase. In the grain mount samples, the mineral biotite was not found associated with other minerals. Thus its representation in Table VII accounts for its presence in each sample as separate mineral grains. Palagonite, when encountered, was counted as a single component. Sedimentary rock fragments include quartzite, detrital quartz grains, cryptocrystalline quartz (chert), and very fine-grained particles composed of quartz and feldspar.

Working with oils of known refractive indices it was found that many of the volcanic rock fragments in grain mount sample numbers $4,6,8$, and 9 contain brown glass with a refractive index of $1.583 \pm 0.001$. According to Williams and others (1954), this indicates a silica content of $50 \pm 1$ percent. This is within the range that Williams sets for rocks of basic composition (45 to 52 percent silica). This information agrees with Trimble's (1963) conclusion that these brown glass particles are basaltic glass (sideromelane). Considering the labile nature of these components, plus the fact that many of these grains are angular, it seems certain that these components were derived from proximal sources.

The data in Table VII show that sedimentary rock fragments are present in some of the grain mount samples. 
The representation of this component reaches a maximum value of 17 percent in sample number 2. Sample number 10 contains 11 percent of this component, nearly all of which is composed of detrital quartz grains, some of which exhibit shadowy extinction and contain trains of spherical crystallites, typical of metamorphic quartz. The literature contains no proof that there are or were rocks composed of these materials, located in proximal regions, that are pre-Troutdale in age. This information indicates that this component represents distal source rocks. The literature contains no information which shows that biotitebearing rocks of pre-Troutdale age, are or were located in proximal source regions. This suggests that the presence of biotite reflects sediment contribution from distal source rocks. Table VII shows that the samples with the two greatest percentages of biotite coincide with the samples which contain the two greatest percentages of sedimentary rock fragments. This reinforces the conclusion that distal source rocks contributed materials to the coarse sand fraction of the deposits of the Troutdale Formation in the study area.

Orthopyroxene, particularly hypersthene, is common in such metamorphic rocks as granulites, charnokites, and thermally metamorphosed shales (Nockolds and others, 1978, and Battey, 1975). Hypersthene also occurs in basalts and andesites (Williams and others, 1954). According to the literature, no pre-Troutdale rock types such as 
these are or were present in proximal regions. Orthopyroxene attains its greatest representation at grain mount sample locality number 1 (Figure 12). The absence of other distallyderived components in this sample suggests that the orthopyroxene was locally-derived. The next two largest percentages of orthopyroxene are represented in sample numbers 3 and 7. These sample localities are well to the south of the study area, outside the influence of the ancestral Columbia River (Bretz, 1917). These two samples do not contain distally-derived components such as sedimentary rock fragments. This information suggests that the orthopyroxene of these samples is locally-derived, such as from basalts and/or andesites of the Cascade Range.

\section{Compositional Trends}

Referring to Table IV and Figure 11 , it is apparent that at the lowest elevation and at the western extreme of the area sampled, the gravel is composed of basalt (sample locality number 1 ). In contrast to this, at the highest elevation and at the eastern extreme of the area sampled, the representation of basalt is 76 percent (sample locality number 4). This data, considered alone, would suggest that the dominance of basalt increases in a westward direction, to the exclusion of all other rock types at locations anywhere west of sample locality number 1 . However, there is no such simple trend of increasing basalt content in a westward direction, because at sample locality 
number 2, which is west of locality number 4 , the proportion of basalt is lower ( 69 percent versus 76 percent).

From the data in Table VII, biotite appears to be restricted to areas north of Gordon Creek (locality number 8, Figure 12). Sedimentary rock fragments appear to be restricted to areas north of the Bull Run River (locality number 9, Figure 12). Both biotite and sedimentary rock fragments attain their maximum representation along the Columbia River at locality number 2. The association of biotite and sedimentary rock fragments near the Columbia River suggests that the ancestral Columbia River was responsible for transporting these distally-derived components. The absence of these components in areas south of the Bull Run River suggests that the influence of the ancestral Columbia River was restricted to areas north of the present day Bull Run River. The orthopyroxene of grain mount sample numbers 3 and 7 (Table VII and Figure 12) probably came from relatively nearby sources, such as the Cascade Range.

The petrographic data shows that much of the Troutdale rocks are composed of mafic volcanic detritus. Mafic volcanic sources of pre-Troutdale age were abundant in the vicinity of the study area. Considering the labile nature of these components, and abundant nearby source rocks, it seems certain that most of the Troutdale rocks were derived from proximal sources. While proximal sources contributed most of the Troutdale rocks, distal sources 
provided significant amounts of detritus to the Troutdale Formation in the study area (25 percent quartzite, Table IV, and 17 percent sedimentary rock fragments, Table VII).

\section{PALEOCURRENT DIRECTIONS}

To provide information regarding paleocurrent directions in the study area, 60 measurements were made on various primary sedimentary structures. Specifically, the structures measured include dip directions of bedding planes, dip directions of foreset beds, direction of imbrication in beds containing imbricated clasts, and the direction of the axis of a channel fill structure. Table VIII lists the localities of the measured structures, as well as the corresponding measured section and petrographic sample localities. This table also lists the types of structures measured, and the measured values. In order to provide a visual display of the data, Figure 13 is constructed according to the following procedure. The measured values at each of the nine locations are averaged, and the averaged values so obtained are plotted as arrows on Figure 13, their directions corresponding to the averaged values or bearings, which are also given alongside the arrows. It is apparent from this display that the agent or agents which carried and deposited the sedimentary rocks of the Troutdale Fromation in the study area flowed in a direction with a strong westerly component. 
TABLE VIII

SUMMARY OF PALEOCURRENT DATA

\begin{tabular}{|c|c|c|}
\hline $\begin{array}{l}\text { Location of paleo- } \\
\text { current measurements }\end{array}$ & $\begin{array}{l}\text { Sedimentary } \\
\text { feature measured }\end{array}$ & $\begin{array}{l}\text { Measured values, in } \\
\text { degrees from north } \\
\text { (bearing) }\end{array}$ \\
\hline 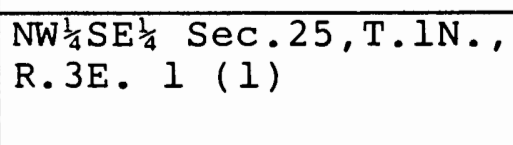 & $\begin{array}{l}\text { axis of trough } \\
\text { in coarse sand- } \\
\text { stone }\end{array}$ & $320,325,325$ \\
\hline 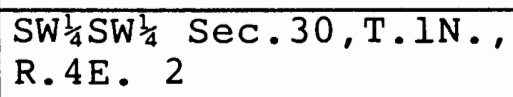 & bedding planes & 325,320 \\
\hline $\begin{array}{l}\mathrm{SW}_{\frac{1}{4} \mathrm{NW}^{\frac{1}{4}}} \mathrm{Sec} \cdot 31, \mathrm{~T} .1 \mathrm{~N} . \\
\text { R. } 4 \mathrm{E} .3\end{array}$ & bedding planes & 340,345 \\
\hline $\begin{array}{l}\text { SW } \frac{1}{4} \operatorname{Sec} \cdot 31, T_{1} \cdot 1 \mathrm{~N} ., \\
\text { R.4E. } 4\left(2,1 *^{*}\right)\end{array}$ & bedding planes & $320,335,340$ \\
\hline $\begin{array}{l}\mathrm{N}^{\frac{1}{2}} \mathrm{Sec} \cdot 6, \mathrm{~T} \cdot 1 \mathrm{~S} \cdot \mathrm{S}^{\prime} \\
\mathrm{R} .4 \mathrm{E} \cdot 5(3,2,5)\end{array}$ & $\begin{array}{l}\text { foreset beds, } \\
\text { bedding planes }\end{array}$ & $\begin{array}{l}240,235,225,230, \\
230,235,220\end{array}$ \\
\hline 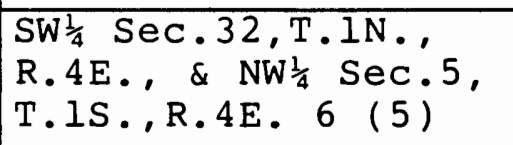 & bedding planes & $\begin{array}{l}275,285,285,295, \\
295,270,275,280\end{array}$ \\
\hline $\begin{array}{l}\mathrm{NW}_{\frac{1}{4} \mathrm{NW}}^{\frac{1}{4}} \mathrm{Sec}_{2}, \mathrm{~T} .1 \mathrm{~S} . \\
\text { R. } 4 \mathrm{E}, 7(8,-, 6)\end{array}$ & bedding planes & $\begin{array}{l}310,305,295,320, \\
305,235,310,335, \\
285,315,305,245, \\
245,255,235\end{array}$ \\
\hline $\begin{array}{l}\mathrm{N}^{\frac{1}{2}} \text { Sec. } 24, \mathrm{~T} .1 \mathrm{~N}, \\
\mathrm{R} .4 \mathrm{E} .8(10,5,1)\end{array}$ & $\begin{array}{l}\text { imbricated clast } \\
\text { beds, bedding } \\
\text { planes }\end{array}$ & $\begin{array}{l}300,280,295,280, \\
290,285,295,275, \\
285,295,305\end{array}$ \\
\hline $\begin{array}{l}\mathrm{N}^{\frac{1}{2}} \text { Sec.19,T.1N., R.5 } \\
\text { E. } 9(10,4,2)\end{array}$ & bedding planes & $\begin{array}{l}260,275,260,265, \\
250,260,245,240, \\
260\end{array}$ \\
\hline
\end{tabular}

The average of all these preceding measurements: $285^{\circ}$. The numbers which follow the map locations corresond to those shown on Figure 13. One or more numbers in parentheses, following the paleocurrent measurement locality number, indicate the following: The first number is the number of the corresponding measured section, located in Figure 6, and depicted in Figure 8 . The second number is the number of the corresonding pebble count sample locality, located in Figure 11. The third number is the number of the corresponding grain mount petrographic sample locality, located in Figure 12. The asterisk indicates the corresponding location where the basalt clasts were sampled, for INAA. 


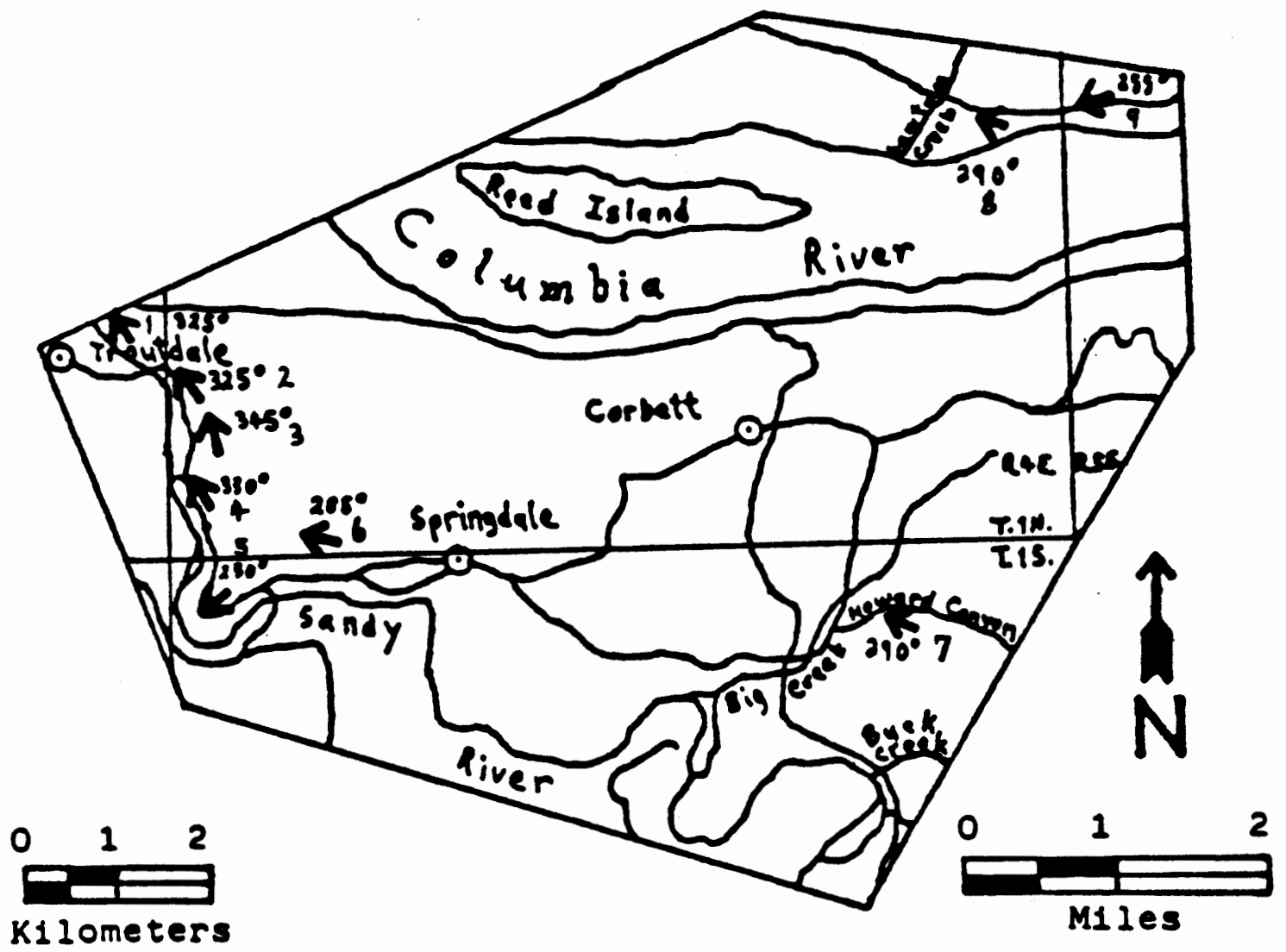

F1gure 13. Map of study area, showing the locations and directions of averaged paleocurrent measurements. The numbers next to the paleocurrent arrows corresnond with those in Table VIII. 
Grand average direction: $285^{\circ}$
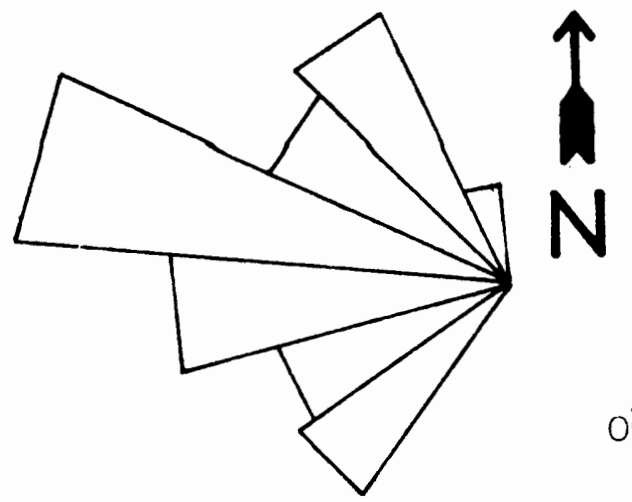

Scale : $200 \mathrm{~mm}=100 \%$

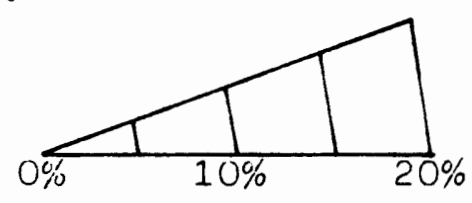

Figure 14. Rose diagram representation of paleocurrent data, tabulated in Table VIII.

A more graphic representation of the paleocurrent data is shown in Figure 14. This figure is a rose diagram, which is a type of frequency distribution. The seven class intervals are $20^{\circ}$ wide, and they encompass the range of the measured values. The size of each $20^{\circ}$ interval represents the percentage of all the measurements which each interval bounds. According to the scale on the diagram, the greatest concentration of measured values falls within a range of $275^{\circ}$ to $295^{\circ}$. This class is centered about a bearing of $285^{\circ}$, which coincides with the average of all the sixty measured values. This reinforces what Figure 13 demonstrates, which is this: the main or dominant direction of travel of the medium or media which carried the sedimentary rocks of the Troutdale Formation, and from which these clastic materials were deposited, was westward. The other class intervals may suggest that 
streams flowing from the northeast and southeast also made contributions to the deposits of the Troutdale Formation.

The presence of both distally-derived and proximallyderived sediments, the distribution of these components, and the granulometric characteristics of the Troutdale sediments, combined with this paleocurrent data, suggest that the ancestral Columbia River was a braided stream, and was the main medium which carried and deposited the Troutdale sediments in the study area. Although other streams flowing from the northeast and southeast may have also made contributions to the Troutdale deposits, the other class intervals of Figure 15 could also be reflecting the presence of side channels, distributaries, and/or anabranches of the main, ancestral Columbia River, which are common in the braided stream depositional environment. 


\section{DEPOSITIONAL ENVIRONMENT}

Two basic models were considered, regarding the environment within which the sedimentary rocks of the Troutdale Formation were deposited. One depositional model, the alluvial-fan, was ruled out because the sedimentary rocks of the Troutdale Formation are not distributed in radial patterns, with a discernable apex and a discernable toe, typical of an alluvial-fan's geometry (Bull, 1972). The other model considered is that of the braided-stream depositional environment.

Williams and Rust (1969) studied the Donjek River, which they classify as a braided stream. They state that in the braided stream environment, gravel (mean grain size greater than $-1.0 \emptyset$ ) is the most abundant lithotype. This is also true for the sedimentary rocks of the Troutdale Formation in the study area, because Table I shows that $\mathrm{M}_{\mathrm{Z}}$ of the conglomerate lithofacies is $-3.6 \emptyset$, and Table II shows that conglomerate is the most abundant lithofacies. The cumulative size frequency curves of Williams and Rust (1969) suggest that there is a great variation in both grain size and grain size distribution within the braided-stream environment. The cumulative size frequency curves shown in Figure 5 demonstrate that, like the sediments of the Donjek River, the sedimentary 
rocks of the Troutdale Formation vary greatly in both grain size and grain size distribution. These conditions seem to be characteristic of the braided-stream environment of deposition.

Williams and Rust (1969) show that in the braidedstream depositional environment, following gravel as the most abundant lithotype, the next most abundant lithotypes are composed of sand and silt, which commonly occur together. The sieve analysis and the measured sections data show that, after the conglomerate, the most abundant lithofacies (equivalent to the lithotypes of Williams and Rust) are the coarse-grained sandstone lithofacies and the siltstone lithofacies. As mentioned above, sand and silt occur together in the siltstone lithofacies of the Troutdale Formation in the study area, such as along the Sandy River at the Stark Street Bridge.

Smith (1970) studied the modern South Platte-Platte River and the ancient Shawangunk and Green Pond Conglomerates. He states that coarse, poorly sorted sediments favor the formation of longitudinal bars. The sieve analysis data show that the sedimentary rocks of the conglomerate lithofacies of the Troutdale Formation are coarse and poorly sorted, which suggests that these rocks may represent ancient longitudinal bars. Smith (1970) says that avalanche faces sometimes develop on the downstream margins of longitudinal bars, and usually have coarse upstream ends which grade into finer-grained downstream ends. Several 
outcrops of the conglomerate lithofacies of the Troutdale Formation in the study area exhibit planar beds which dip as much as $31^{\circ}$ in a downstream direction. Some of these outcrops also expose rocks which grade from a cobble conglomerate to a coarse-grained sandstone, in a downstream direction. The rocks in these outcrops probably represent ancient longitudinal bars, characteristic of the braided stream environment of deposition.

Smith's (1970) study of the braided stream depositional environment shows that longitudinal bars tend to have a high bed relief index (BRI). Figure 10 shows a BRI value of 12.1 for one outcrop of the conglomerate lithofacies of the Troutdale Formation in the vicinity of measured section locality number 10 (Figures 6 and 8 ), which exhibits irregular-lenticular bedding. The study of Smith (1970) suggests that this high BRI value of 12.1 is what one would expect of proximally-located sedimentary rocks within the braided-stream depositional environment. Although the granulometric character of the outcrop suggests that the rocks here were proximally derived, the compositional data (Tables IV and VII) show that much of the detritus came from distal sources. 
SUMMARY

Qualitative inspection of the Troutdale Formation in the study area reveals that three granulometrically distinct and recognizable lithofacies are present. Sieve analyses of samples collected in the type locality, confirm in quantitative terms that at the sample localities, three distinct lithofacies are indeed present. These lithofacies are called the conglomerate, the coarse-grained sandstone, and the siltstone lithofacies. More sieve analyses need to be performed on the sedimentary rocks of the Troutdale Formation throughout the region in order to establish a firm foundation for the usage of these informal lithofacies terms, and in order to establish the range in granulometric parameters necessary for describing the distinguishing characteristics of each lithofacies. Despite the lack of extensive granulometric data, the information of the present report provides a sufficient basis for the recognition, description, and further study of the Troutdale Formation.

The methods used in the sieve analyses section of this report follow the procedures of Folk (1974). The mean grain size $\left(\mathrm{M}_{Z}\right)$ of the conglomerate and the coarsegrained sandstone lithofacies are, repsectively, $-3.6 \emptyset$ and $1.0 \emptyset$. The sorting $\left(\sigma_{I}\right)$ for these lithofacies are 
2.0 (poorly to very poorly sorted) and 0.96 (moderately sorted). The cumulative size frequency curves show that the sedimentary rocks of the Troutdale Formation vary greatly in grain size and grain size distribution. Sand and silt occur together in the siltstone lithofacies. The sands in the coarse-grained sandstone lithofacies are the best sorted of the three lithofacies.

The data from the measured sections show that in the study area, conglomerate is the dominant lithofacies, with an estimated volume proportion of 56 to 60 percent. The coarse-grained sandstone lithofacies makes up 34 to 38 percent of the Troutdale Formation's exposures, while the siltstone lithofacies forms a minor part of the Troutdale Formation, with 4 to 8 percent. The measured sections data allows the development of a representative composite section of the Troutdale Formation in the study area. This composite section is shown diagrammatically in Figure 9 and described above. During the field work for one of the measured sections, an outcrop of the conglomerate lithofacies which exhibits irregular-lenticular bedding was measured, from which its bed relief index (BRI) was calculated, according to the procedures of Smith (1970). The BRI of this outcrop is 12.1 .

The pebble count data show that basalt is the dominant rock type of the conglomerate lithofacies in the study area. Its minimum representation over the five sample lcoalities is 69 percent. Its maximum is 100 percent, 
and its average is 85 percent. Quartzite is the next most abundant rock type, reaching a maximum representation of 25 percent, and averaging 9 percent.

The instrumental neutron activation analysis (INAA) shows that at least one formal member (Frenchman Springs) and two informal members (Grand Ronde Basalt, High Mg and Low Mg) of the Columbia River Basalt Group were sources for the sedimentary rocks of the Troutdale Formation in the study area. The INAA data also show that rocks of the Boring Lavas or similar lavas were sources which contributed material to the Troutdale Formation.

The grain mount petrographic data show that volcanic rock fragments are the dominant component in the coarse sand fraction of the Troutdale Formation in the study area. Many of these volcanic rock fragments contain brown glass which has an index of refraction of $1.583 \pm 0.001$, which indicates a mafic composition. The representation of sedimentary rock fragments averages 5 percent, with a maximum of 17 percent. Biotite averages 2 percent, with a maximum of 12 percent. Four of the six samples which contained sedimentary rock fragments also contained biotite. The representation of orthopyroxene averages 5 percent with a maximum of 18 percent. The samples with the three largest amounts of orthopyroxene $(18,16$, and 10 percent) do not contain any sedimentary rock fragments or biotite. 
The grand average bearing of 60 paleocurrent measurements is $285^{\circ}$. A rose diagram representation of the paleocurrent data shows the class interval with the greatest percentage of measurements is centered about a bearing of $285^{\circ}$. Other class intervals indicate the presence of streams flowing in northwesterly and southwesterly directions.

The granulometric data, the measured sections data, and the BRI calculation, when compared with literature data, suggest strongly that the sedimentary rocks of the Troutdale Formation in the study area were deposited in the braided-stream depositional environment. The peoble count, INAA, and grain mount petrographic data show that most of the Troutdale rocks were derived from proximally-located sources. Distal sources however, contributed significant amounts of such components as quartzite, sedimentary rock fragments, and biotite. The granulometric characteristics of some of the Troutdale rocks are typical of proximal areas within the influence of the braided-stream environment of deposition, despite the presence of distally-derived components.

Tolan (1982) informally proposes an upper member of the Troutdale Formation which is mostly basaltic and vitric, and a lower member which is quartzitic, micaceous, and arkosic. Projecting downstream the channel direction from where the Troutdale Formation is exposed in the canyon of Bridal Veil Creek, the Troutdale Formation is exposed 
in the vicinity of Mt. Pleasant (Tolan, 1982, personal communication). A pebble count and grain mount sample were collected in this area. The samples came from high in the section, since the sample localities were within approximately 50 vertical meters of the overlying Boring Lavas. If in fact this is high in the section, then the rocks should exhibit basaltic and vitric characteristics of Tolan's upper member. Tables IV and VII show that the compositional characteristics of the Troutdale Formation here is quartzitic, micaceous, and arkosic, like Tolan's lower member. Further work is needed to establish whether the Troutdale Formation here is correlative with Tolan's lower member of the Troutdale Formation. 


\section{REFERENCES CITED}

Allen, J.E., 1932, Contributions to the structure, stratigraphy, and petrography of the lower Columbia River Gorge: University of Oregon, Master's Thesis, p. 96.

---- 1979, The Magnificent Gateway: Timber Press, p. 144 .

Anderson, J., 1980, Pomona Member of the Columbia River Basalt Group: an intracanyon flow in the Columbia River Gorge, Oregon: Oregon Geology, v. 42, no. 12, p. 195-199.

Battey, M.H., 1975, Mineralogy for students: Longman Group Limited, p. 323.

Beeson, M., Johnson, A., and Moran, M., 1975, Portland environmental geology - fault identification: Portland State University, in cooperation with DOGAMI, sponsored by the U.S. Geological Survey, p. 107.

----, and Moran, M., 1979, Columbia River Basalt Group stratigraphy in Western Oregon: Oregon Geology, v. 4l, no. $1, \mathrm{p} .11-14$.

Blatt, H., Middleton, G., and Murray, R., 1972, Origin of sedimentary rocks: Prentice-Hall Inc., p. 634.

Bretz, H., 1917, The Satsop Formation of Oregon and Washington: Jour. Geology, v. 25, no. 5, p. 446-458.

Bull, W., 1972, Recognition of alluvial-fan deposits in the stratigraphic record: S.E.P.M. Special publication \#16, p. 63-83.

Chaney, R., Condit, C., and Axelrod, D., 1944, Pliocene floras of California and Oregon: Contributions to Paleontology, p. 407 .

Deer, W.A., Howie, R.A., and Zussman, J., 1975, An introduction to the rock forming minerals: Longman Group Limited, p. 528.

Fahnestock, R.K., 1963, Morphology and hydrology of a glacial stream: U.S. Geological Survey Prof. Paper $422-A, p .1-70$. 
Folk, R., 1974, Petrology of sedimentary rocks: Hemphill Publishing Company, p. 182 .

Goddard, E.N., Trask, P.D., DeFord, R.K., Rove, O.N., Singewald, J.T. Jr., and Overbeck, R.M., 1975, G.S.A. rock-color chart: Geol. Soc. America, p. 10 .

Hamblin, K.W., and Howard, J.D., 1975, Exercises in physical geology: Burgess Publishing Company, p. 233.

Hodge, E., 1938, Geology of the lower Columbia River: Geol. Soc. America Bull., v. 49, no. 6, p. 831-930.

Lowry, W., and Baldwin, E., 1952, Late Cenozoic geology of the lower Columbia River Valley, Oregon and Washington: Geol. Soc. America Bull., v. 63, no. 1, p. $1-24$.

Matthews, R.K., 1974, Dynamic Stratigraphy: PrenticeHall, Inc., p. 370 .

Nockolds, S.R., Knox, R.W., and Chinner, G.A., 1978, Petrology for students: Cambridge University Press, p. 435 .

Schlicker, H.G., and Deacon, R.J., 1967, Engineering geology of the Tualatin Valley region, Oregon: Ore. Dept. Geol. and Min. Inds. Bull. 60, p. 88 .

Smith, N., 1970, The braided stream depositional environment: comparison of the Platte River with some Silurian clastic rocks, north-central Appalachians: Geol. Soc. America Bull., v. 81, p. 2993-3014.

Swanson, D.A., Wright, T.L., Hooper, P.R., and Bentley, R.D., 1979, Revisions in stratigraphic nomenclature of the Columbia River Basalt Group: U.S. Geol. Survey Bull. 1457-G, p. 59.

Tolan, T., 1982, Unpublished Master's Thesis.

Treasher, R., 1942, Geologic map of the Portland area, Oregon: Ore. Dept. Geol. and Min. Inds.

Trimble, D., 1963, Geology of Portland, Oregon, and adjacent areas: U.S. Geological survey Bull. $1119, \mathrm{p}$. 119 .

Williams, H., Turner, F.J., and Gilbert, C.M., 1954, Petrography: W.H. Freeman and Company, p. 406. 
Williams, I.A., 1916, The Columbia River gorge: its geologic history interpreted from the Columbia River Highway: Oregon Bur. Mines and Geology, Mineral Resources of Oregon, v. 2, no. 3 .

Williams, P.F., and Rust, B.R., 1969, The sedimentology of a braided river: Journal of Sedimentary Petrology, v. 39, no. 2, p. 649-679. 
$000000000 \infty$ $m m m m m+m+m n$ $\cup$ 0

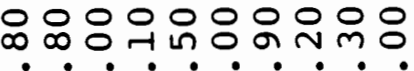
NRR 00 - 0 \&mm $m m m m m * N * m m$

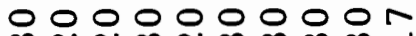
mNNmNmmmm - $\dot{0} 0$ ம 0

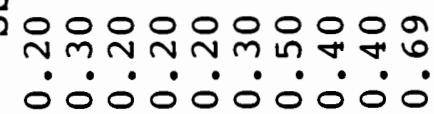

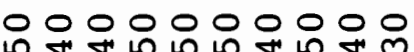
$\cdot \cdot \cdot \cdot \cdot \cdot \cdot \cdot \cdot 0$ 0000000000 ㄴํㅅำ . ! ! ! ! ! ! $\dot{m} \dot{m} \dot{\sim} \dot{m} \dot{m} \dot{m} \dot{\sim} \dot{m}$

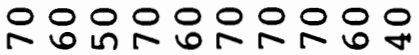
ம $\dot{0} \dot{0} \dot{0} \dot{0} \dot{0} \dot{0} \dot{0}$ r

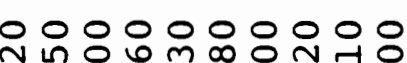
$\bullet \cdot \bullet \cdot \cdot \cdot \cdot \cdot \cdot 0$ ก

mก 0000000000 0000000000 3 ㅅํํำ $\therefore \cdot \dot{0} \cdot \dot{0} \cdot \dot{0}$

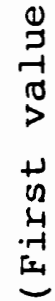

$\infty \Gamma+\infty N a \infty \infty \infty$ in 00000000000

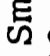
0000000000

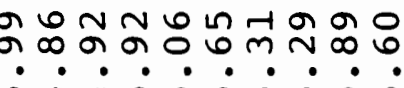
ம

$\frac{1}{8}$

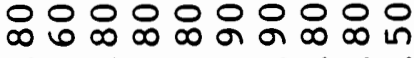

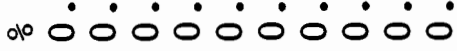

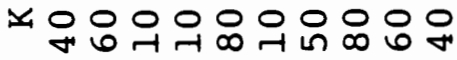
$\dot{0} \dot{0} \dot{0} \dot{0} \dot{0} \dot{0}$

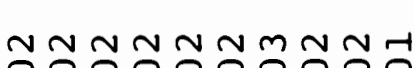
$\because: 0.0 .0$ do 00000000000 TOmHNNMOFLm z\&n N $\sim \sim \dot{N} \sim \dot{N} \sim$

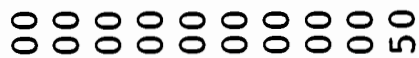
o mm $\mathrm{n} \sim \dot{\mathrm{m}} \mathrm{m} \dot{\mathrm{N}}$

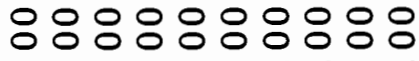
E्-

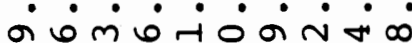
$m m m m m \neq m \forall m m$

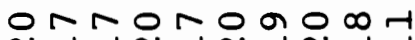
NHANHNHNH 이 0000000000

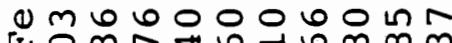
घ 0 m

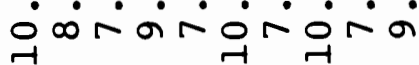

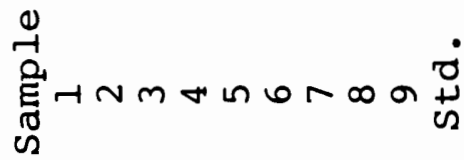


응ㅇㅇㅇㅇㅇㅇㅇㅇㅇㅇㅇㅇ 0ं0்0்000்

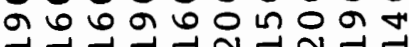

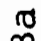

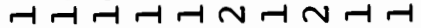
m

ㅇㅇㅇㅇㅇㅇ․ $\dot{0} \dot{0} \dot{0} 0 \dot{0} 0$ Go

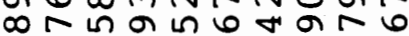

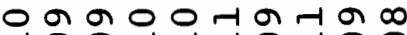
न כ 0000000000 1 Ho 0 in $m$ r

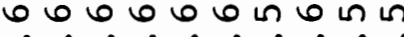
○ $\dot{0} \dot{0} \dot{0} \dot{0} \dot{0} \dot{0} \dot{0} 0$

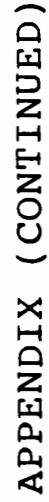

(1)

응ㅇㅇㅇㅇㅇㅇㅇㅇㅇㅇㅇㅛ $\dot{\sim} \dot{\sim} \dot{\sim} \dot{\sim} \dot{\sim} \dot{m} \dot{\sim} \dot{H}$

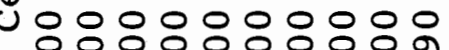
西 $\dot{\sigma} \dot{\infty} \dot{\infty} \dot{\sim} \dot{\sim} \dot{0} \dot{\sim} \dot{m}$ 几

0 \% $\infty 0$ क 0 का ना क

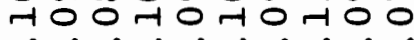
2

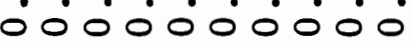

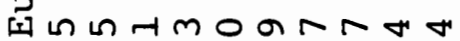
ti $\infty$ in a न $N$ o $\dot{v} \dot{H} \dot{N} \dot{H} \dot{\sim} \dot{N} \dot{N} \dot{H}$

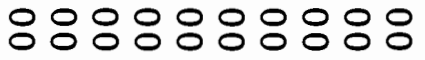
Z 0
$\pi$

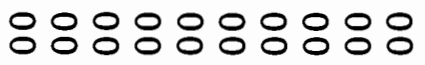
i H $m \sim m m \sim m \sim N N$

0000000000

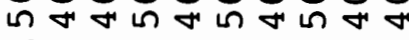
2 0000000000

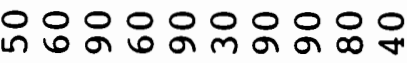
! ! ! ! ! ! ! m $\dot{\sim} \dot{\sim} \dot{\sim} \dot{\sim} \dot{\sim} \dot{\sim}$

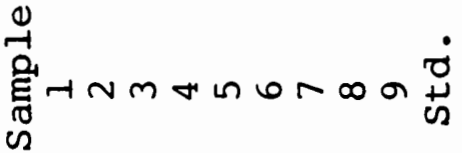

0000000000 ก 당

0000000000

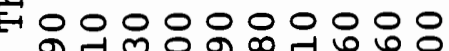
$\dot{0} \dot{0} \dot{m} \dot{m} \dot{*} \dot{m} \dot{0}$

0000000000 No $0_{1} m_{-1} m-1 \infty$

U

નનન-નન-નમા

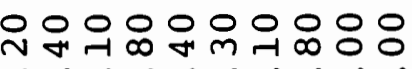

$\cdot \cdot \cdot \cdot \cdot \cdot \cdot \cdot \cdot \cdot$ A

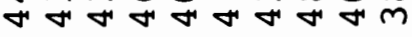

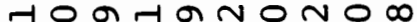
न 0000000000 (1)

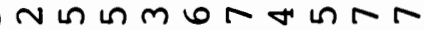
$m$ б ब व स - $\dot{\sigma} \dot{\infty} \dot{0} \dot{-1} \dot{\infty} \dot{\vec{\sigma}} \dot{\sigma}$

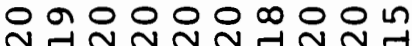
N.TNNNNH N N U 0000000000 (2) ᄂ $\cdot \dot{0} \cdot \dot{0} \cdot \dot{0} \dot{0}$

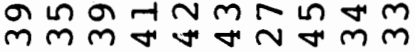

0000000000 o - $\dot{0} \dot{0} \dot{0} \dot{0} \dot{0} \dot{0}$ $\overleftrightarrow{4}$

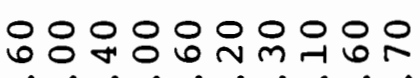
$\bullet \bullet \bullet \bullet \bullet \cdot \dot{0} \cdot \dot{0} \dot{0}$

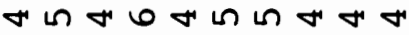

ㅇㅇㅇㅇㅇㅇㅇㅇ

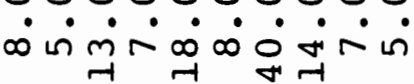

y - $\cdot . \cdot \cdot \cdot \cdot \cdot \cdot$ oN OmmNoma $\sim-6 \sim \infty \sim \infty$

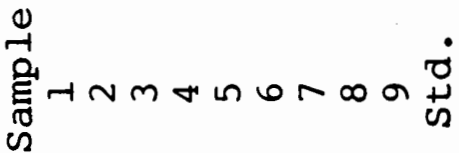

